\title{
FORMAS INTERIORES Y EXTERIORES DE LA RELIGIÓN EN LA BAJA ANDALUCÍA DEL RENACIMIENTO. ESPIRITUALIDAD FRANCISCANA Y RELIGIOSIDAD POPULAR
}

\author{
POR \\ RAFAel M. PÉrez García \\ Universidad de Sevilla
}

\section{RESUMEN}

Este artículo investiga los orígenes intelectuales del modelo de análisis que ha primado en el estudio de la espiritualidad y de la religiosidad popular en la España del Renacimiento. A partir del estudio concreto de la espiritualidad franciscana en el marco de la Baja Andalucía, se pretende replantear dicho modelo y sentar las bases de un nuevo paradigma historiográfico más atento a las formas históricas de la religión y consciente de las construcciones ideológicas con que se la ha presentado en el transcurso del tiempo.

PALABRAS CLAVE: Espiritualidad, religiosidad popular, franciscanismo, siglo XVI, historiografía.

\section{INTERIOR AND EXTERIOR RELIGION FORMS IN WEST ANDALUSIA DURING THE RENAISSANCE}

\begin{abstract}
This paper examines the intelectual roots of the traditional research approach to deal with spirituality and popular religiosity in Renaissance Spain. I propose an alternative approach. On the basis of the case study of franciscan spirituality in West Andalusia, this alternative approach exemplifies the need to accommodate in research studies: (i) a more historical perspective of religion; (ii) the coherence between external and internal forms of religion. My approach unveils standard ideological inertias present in the traditional approach, as well as a lack of historical perspective.
\end{abstract}


KEY WORDS: Spirituality, popular religion, franciscanism, XVI century, historiography.

Recibido/Received 16-06-2008

Aceptado/Accepted 20-11-2008

INTERIORIDAD Y EXTERIORIDAD EN LOS ESTUDIOS SOBRE LA RELIGIÓN EN EL RENACIMIENTO

El estudio de la religión en la Baja Andalucía de fines del Medievo y del Renacimiento se ha caracterizado por su fraccionamiento en una serie de subcampos de estudio, como consecuencia clara y directa de los modos en que se ha construido el conocimiento historiográfico, antropológico y teológico, antes que de una apreciación históricamente equilibrada de la complejísima realidad religiosa y eclesiástica de la época. Así, podemos delimitar los siguientes subcampos:

1) la historia eclesiástica en sentido estricto, ocupada tanto de la estructura diocesana, obispados, la parroquia, el sostenimiento económico con especial atención al diezmo, ... como de las órdenes religiosas, y que en los últimos años se ha visto «revolucionada» por el enfoque de la confesionalización y el disciplinamiento social;

2) el estudio de la religiosidad popular;

3) la historia espiritual o de la espiritualidad, que suele correr paralela al estudio de la literatura espiritual;

4) las otras religiones, judía y musulmana, que desde los años 1492 y 1502 respectivamente pasan a convertirse en cripto-religiones a consecuencia de las disposiciones de los Reyes Católicos de conversión obligatoria al cristianismo; islamismo y cripto-islamismo que van a tener una presencia mucho mayor en la otra Andalucía, la del Reino de Granada, y que, paradójicamente, será a raíz de la derrota morisca en la Segunda Guerra de Granada (1568-1570) y la consiguiente deportación general de los granadinos por la Corona de Castilla cuando se «importe» el problema en grandes dimensiones al valle del Guadalquivir hasta la definitiva expulsión de 1610.

5) y, por último, el estudio de una institución, la Inquisición, que aparece en el periodo y que va a condicionar decisivamente todos los ámbitos del hecho y de la realidad religiosa, así como su evolución desde finales del siglo XV en adelante.

En este trabajo queremos centrar nuestra atención en las relaciones que existieron en la Baja Andalucía en la época del Renacimiento entre la religiosidad 
popular con la espiritualidad, atendiendo al marco eclesiástico general, secular y regular, en el que aquellas se produjeron. Este estudio se hace más necesario en tanto que ambas religiosidades han sido tratadas por los estudiosos de modo netamente separado, sin establecer, en general, ningún tipo de relaciones entre ambas, y creando, de este modo, una clara disociación en la investigación entre los dedicados a la religiosidad popular, y todo lo que se suele asociar a ella, y los ocupados en la Historia de la espiritualidad. De este planteamiento epistemológico, implícita aunque no conscientemente asumido por la mayoría de los investigadores, se ha derivado una apreciación fragmentaria de la experiencia religiosa de la época.

En nuestra opinión, esta dualidad es consecuencia del modo en que se ha construido a lo largo del siglo XX el conocimiento historiográfico sobre la religión cristiana en la Baja Andalucía, y en España en general, en la época que transcurre desde la Baja Edad Media hasta, al menos, el primer tercio del siglo XVII. En este sentido, el desarrollo «peculiar» de la historiografía dedicada a la espiritualidad a lo largo del siglo XX ha sido decisivo, y en ello jugó un papel fundamental la publicación en 1937 de la gran obra de Marcel Bataillon, «Erasmo y España. Estudios sobre la Historia espiritual del siglo XVI». En un momento en que el horizonte historiográfico español en el terreno de la espiritualidad estaba todavía muy inmaduro e incompleto, el enorme libro de Bataillon sobre el impacto del erasmismo en la cultura y espiritualidad españolas del siglo XVI, a la vez que historiaba la evolución del movimiento en la Península, ofrecía una primera gran síntesis explicativa que lograba encajar en un gigantesco puzzle mucho de lo que entonces se consideraban verdaderos «enigmas» de nuestra Historia espiritual, temas y problemas hasta el momento deshilvanados y entre los que brillaban con atrayente interés la eclosión mística carmelitana, el protestantismo sevillano de mediados de siglo, la herejía alumbrada, así como los orígenes de todo ello, algo que se ligaba en los estudios, a su vez, con las fuentes literarias de los místicos y espirituales en general.

El Enchiridion o manual del caballero cristiano de Erasmo de Rotterdam, publicado en castellano en 1526 y seguido rápidamente de nuevas ediciones al paso de su enorme éxito editorial, es para Bataillon el «manifiesto del cristianismo interior» en el que la «oposición de la carne y del espíritu es el tema mismo del Enquiridion, el punto en torno al cual va a ordenar Erasmo todo su concepto de la esencia del cristianismo... el meollo del libro se encuentra en la regla quinta, que enseña a tener en poco «las cosas visibles» y a levantarse a las invisibles» ${ }^{1}$. En ese cristianismo interior, las obras externas, peregrinaciones, devociones y oraciones a los santos, ayunos, culto a las reliquias, petición

\footnotetext{
${ }^{1}$ Marcel BataIllon, Erasmo y España. Estudios sobre la historia espiritual del siglo XVI, México, 1966, p. 196.
} 
de milagros, enterrarse amortajado con el hábito de San Francisco, etc., sólo tendrían sentido en tanto que ayudasen al cristiano a su propia mejoría moral personal, acercándole a Cristo, y levantándole, así, de la carne, lo externo, al espíritu, lo interior, es decir, las virtudes de Cristo y la pureza de intenciones de la vida evangélica; en caso contrario, esas manifestaciones externas no serían sino expresión de nuevo y grosero paganismo ${ }^{2}$.

A partir de la obra de Bataillon, que estudiaba el erasmismo español y el impacto de la obra de Erasmo en la espiritualidad española, una dilatada corriente historiográfica creó un modelo de análisis histórico que tendió a asociar al erasmismo todo aquello que sonase a libertad, interioridad, acción del Espíritu Santo en la persona, «iluminismo», modernidad, lectura de la Biblia en romance, Cuerpo místico, etc, demostrando así un sorprendente desconocimiento de la tradición espiritual y la teología mística en la historia del cristianismo ${ }^{3}$. Es la línea historiográfica que pasa por Américo Castro ${ }^{4}$, Eugenio Asensio ${ }^{5}$, Márquez Villanueva ${ }^{6}$ y Ángel Alcalá que potencian el ingrediente converso en este modelo ${ }^{7}$, y

${ }^{2}$ Ibid, pp. 190-205.

${ }^{3}$ R. M. PÉrez GARCíA, «Pensamiento teológico y movimientos espirituales en el siglo XVI», en A. L. CoRTÉs PEÑA, Historia del cristianismo, Madrid, 2006, tomo III, pp. 51-90.

${ }^{4}$ Algunas de sus expresiones son muy reveladoras de este planteamiento historiográfico: «El erasmismo del siglo XVI -o sea, el mesiánico y utópico sueño de un catolicismo aliviado de ceremonias enraizadas en la tradición popular, y afanoso de revivir la pura espiritualidad de San Pablo- ...» (A. CAstro, Aspectos del vivir hispánico, Madrid, 1987, p. 9).

5 Especialmente Eugenio ASENSIO, «El erasmismo y las corrientes espirituales afines», Revista de Filología Española 36 (1952), 31-99 y Eugenio AsENSIO, «Los estudios sobre Erasmo, de Marcel Bataillon», Revista de Occidente 63 (1968), 302-319.

${ }^{6}$ Los puntos de vista de Márquez Villanueva quedaron expuestos, por ejemplo, en su «Ensayo introductorio: Hablando de conversos con Antonio Domínguez Ortiz», que precede a la edición facsímil publicada por la Universidad de Granada de A. Domínguez OrTiz, La clase social de los conversos en Castilla en la Edad Moderna, Granada, 1991.

7 Ángel Alcalá, que continúa y desarrolla las tesis de Américo Castro, es claro: «Tanto los escritores como los místicos conversos postulaban una subversión de los valores que la mayoría cristianovieja solía tomar por supuestos e inviolables: la labor de aquellos se centraba en su crítica con un acento personal inconfundible; la vivencia religiosa de estos estaba vivificada por un tipo de religiosidad absolutamente intimista, distinto al exteriorizado de las masas o de la tradición» (Ángel AlCALÁ, «El mundo converso en la literatura y la mística del Siglo de Oro», Manuscrits 10 (1992), 117). Esta implementación del factor converso es limitada en Eugenio ASENSIO, «La peculiaridad literaria de los conversos», Anuario de Estudios Medievales 4 (1967), 327-351, aunque posteriormente Asensio y Bataillon anudan estrechamente los vectores erasmismo-conversos: «Ciertamente, este iluminismo no fue patrimonio exclusivo de los cristianos nuevos. De ellos, sin embargo, es de quienes parece haber tomado su vigor. Si el injerto erasmiano prendió tan bien en el tronco español, se lo debe a esta savia» (M. BATAILLON \& E. ASENSIO, «En torno a Erasmo y España», en Historia y crítica de la literatura española, ed. F. Rico, vol. 2.: «Siglos de Oro: Renacimiento», Barcelona, 1980, pp. 71-84, en concreto p. 76; estas palabras, junto a un cierto énfasis en el carácter determinante jugado por los judeoconversos, aparecen ya en la conclusión del Erasmo y España, pp. 803-804). Una crítica de la interpretación del papel histórico-cultural que según Américo Castro habrían jugado los judeoconversos en la España del

Hispania Sacra, LXI

124, julio-diciembre 2009, 587-620, ISSN: 0018-215-X 
otros hasta llegar a M. L. Giordano ${ }^{8}$, o S. Pastore ${ }^{9}$. Según esta corriente historiográfica ${ }^{10}$, frente a este «cristianismo interior» de matriz erasmianao ${ }^{11}$, europeo y moderno, se situaría la arcaica, supersticiosa y externa religiosidad del pueblo español.

Aunque no es este lugar para entrar en detalles, es interesante poner de relieve las conexiones existentes entre los orígenes intelectuales de este modelo historiográfico con determinadas figuras principales en la renovación del pensamiento español en lo relativo a Religión e Iglesia desde los últimos años del siglo XIX y el primer tercio del siglo XX. Desde luego, el impacto de En torno al casticismo de Unamuno, que tanto gustara y citara Bataillon, es clave. En un sentido similar, son elocuentes las palabras de Manuel Azaña cuando reflexionaba sobre las causas de nuestra Guerra Civil contraponiendo el atraso y la modernidad que convivían a escasos metros en España: "Una corriente vigorosa de libertad intelectual, que en materia de religión se traducía en indiferencia y agnosticismo, junto a demostraciones públicas de fanatismo y superstición, muy distantes del puro sentimiento religioso» ${ }^{12}$. En suma, un par ideológico opuesto en el que volvemos a encontrar contrapuestos, de un lado, «fanatismo» y «superstición» con su vertiente de proyección «pública», es decir, externa-colectiva, y de otro lado, «libertad intelectual» y «puro sentimiento religioso» que parece indicar, en tanto que sentimiento, a algo interior a la persona y sin plasmación externa-social, y que se empareja, antes que con lo anterior, con «indiferencia y agnosticismo». En esta dirección, no son casuales las palabras escritas por Bataillon en el triste agosto de 1936 cerrando su gran libro y relacionando erasmismo con el entonces moderno krausismo:

«... el erasmismo fue un profundo movimiento cultural, cuyas consecuencias llegan muy lejos... En 1931, un heredero espiritual de los krausistas, nombrado ministro de la joven República española, decía en la tribuna de las Cortes constituyentes: "Nosotros que somos los modernos erasmistas...». La comparación no es arbitraria... Movimientos

Siglo de Oro, en Nicholas G. Round: «La peculiaridad literaria de los conversos, ¿unicornio o snarck?, en A. Alcalá (ed.): Judíos. Sefarditas. Conversos. La expulsión de 1492 y sus consecuencias, Valladolid, 1995, 557-575.

${ }^{8}$ M. L. GIORDANO, Apologetas de la fe. Élites conversas entre Inquisición y patronazgo en España (siglos XV y XVI), Madrid, 2004.

${ }^{9}$ S. PAStORE, Un'eresia spagnola. Spiritualità conversa, alumbradismo e inquisizione (14491559), Firenze, 2004

${ }^{10}$ No llegan a este planteamiento los trabajos citados de Stefania Pastore y Laura Giordano.

${ }^{11}$ En palabras de Castro: «Recordemos el esquema más simple a que cabe reducir la gran aventura erasmista del siglo XVI: un ensayo poco preciso de cristianismo interior, una actitud más que un cuerpo riguroso de afirmaciones y negaciones, escaso aprecio por las ceremonias, todo ello encabezado por personas doctas o por aristócratas que, utópicamente, esperaban eludir el peso de la masa y de la tradición» (A. CASTRO, Aspectos del vivir hispánico, Madrid, 1987, p. 47).

${ }^{12}$ M. AzAÑa, Causas de la guerra de España, prólogo de Gabriel Jackson, Barcelona, 1986, p. 23. 
[el erasmismo y el krausismo], asimismo, que tuvieron que empeñar lucha tenaz contra otra España ariscamente antieuropea, enemiga de las novedades... La lucha no ha concluido. Está tomando formas trágicas...»13.

Es en este contexto ideológico en el que hay que entender aquella anécdota acerca de don Fernando de los Ríos, el eminente ministro socialista de la República, que, ante la insistencia de las autoridades norteamericanas de inmigración para que respondiera de modo satisfactorio acerca de su filiación religiosa, se declaró «erasmista» ${ }^{14}$.

Por otra parte, sería de no menor interés estudiar en qué medida el pensamiento republicano español en materia religiosa se vio influido por la propaganda protestante respecto a la realidad del cristianismo en España, una propaganda articulada en torno a una serie de tópicos recurrentes y repetitivos desde el siglo XVI hasta el siglo XX. En este sentido, no es casualidad el interés de Azaña por el libro decimonónico La Biblia en España del inglés George Borrow, misionero de la Sociedad Bíblica Británica y Extranjera en la España de la primera guerra carlista ${ }^{15}$. Un texto tomado de un clásico de la apologética y hagiografía protestante, las Artes de la Inquisición española, puede ser ilustrativo en este sentido. La descripción que hace González de Montes (Heidelberg, 1567) del triunfo de la Reforma protestante en el monasterio de San Isidoro del Campo, junto a Sevilla, refleja a la perfección ese planteamiento que contrapone, al tiempo que valora, interioridad («buena») frente y en contra de exterioridad («mala»):

«Ya las horas, que llaman de coro y rezo, se habian convertido en esplicaziones de la Sagrada Escritura; las preces acostumbradas por los muertos, o se habian suprimido, o en su mayor parte cercenado, anticuándose del todo las indulgencias y expiaciones, en otro tiempo concedidas por los Romanos Pontífices, ... a las imágenes, ningún culto, o muy poco, ciertamente, les era dejado; conmutado se habian los ayunos supersticiosos, en perpetua sobriedad; nadie era ya instruido para el monacato, sino para la verdadera piedad... Ni se encerraba, por eso, aquella divina luz dentro de las paredes del Monasterio, extendiase aun a la ciudad y pueblos circunvecinos, comunicándose por los libros y por la palabra» ${ }^{16}$.

${ }^{13}$ M. Bataillon, Erasmo y España, México, 1966, p. 805.

${ }^{14} \mathrm{~F}$. de los Ríos, Religión y Estado en la España del siglo XVI, edición y notas de Antonio García Pérez, prólogo de Ángel del Río, Sevilla, 2007, p. 41.

15 Azaña tradujo al castellano el libro de Borrow para la primera edición española de 1921. Existen actualmente varias ediciones de Alianza Editorial que siguen utilizando el texto preparado por Manuel Azaña.

16 R. GonZÁlez De Montes, Artes de la Inquisición española, Barcelona, 1981, p. 273. Reimpresión de la primera traducción española publicada en San Sebastián en 1851 (Reformistas Antiguos Españoles, $\mathrm{V})$.

Hispania Sacra, LXI

124, julio-diciembre 2009, 587-620, ISSN: 0018-215-X 
En suma, de nuevo la oposición entre culto a las imágenes-indulgenciasrezo vocal (externo)-Iglesia Católica Romana frente a Biblia-«verdadera piedad»-autenticidad de la acción de Dios («divina luz»)-libros. Este esquema es el que sigue repitiendo exactamente Borrow en el siglo XIX, constituyendo, en palabras de Fernando Bouza, «uno de los tópicos más extendidos de que se nutre la historia religiosa y cultural de Occidente» ${ }^{17}$. En esta misma línea sería necesario investigar también cómo las concepciones religiosas del republicanismo español podrían haber bebido, desde el punto de vista historiográfico, en la historiografía decimonónica protestante alemana sobre la Reforma Protestante y su significación en la Historia de Europa (Leopold Ranke en 1839-1847, Friedrich V. Bezold en 1886, y Paul Joachimsen en 1930), vinculando a ella una vuelta a «las formas puras del cristianismo», «renovación de la religión sobre la base de la autodeterminación del individuo», etc, así como en la obra de Wilhelm Dilthey (1833-1911), que considera a la Reforma como fase y causa del sistema científico del siglo XVII ${ }^{18}$.

En mi opinión, el enorme influjo del «Erasmo y España» y de la historiografía que lo ha glosado y continuado durante décadas, está, en buena medida, en el origen de la disociación entre los estudios de espiritualidad y los de religiosidad popular del siglo XVI, consecuencia de haber desligado ambas realidades en ámbitos distintos directamente dependientes de la dualidad «cristianismo interior-interioridad-en espíritu-espiritualidad» frente al «cristianismo externosuperficialidad-religiosidad popular». Esos elementos religiosos externos quedaron olvidados para los historiadores de la religión en el XVI, centrados en lo valorado como «positivo», la espiritualidad, y olvidando un inmenso campo de estudio, el de la religiosidad denominada popular que quedó para los folkloristas y para los antropólogos ${ }^{19}$. Sólo después volvió el interés de los historiadores hacia ella: primero, los interesados (P. Burke, M. Bajtin, C. Ginzburg, ...) en «redescubrir» la «cultura popular» en su fase terminal, la época del proceso civilizatorio (N. Elias); y, finalmente, los historiadores culturales interesados por la Religión han vuelto también sus ojos hacia ella ${ }^{20}$.

17 F. J. BouZa Álvarez, «Contrarreforma y tipografía. ¿Nada más que rosarios en sus manos?», Cuadernos de Historia Moderna 16 (1995), 74.

${ }^{18}$ H. LuTz, Reforma y Contrarreforma, Madrid, 1992, pp. 203-207.

${ }^{19}$ En este sentido hemos de recordar a Julio Caro Baroja, primero, y después a Carmelo Lisón Tolosana como los dos grandes padres de la antropología española, y, muy especialmente, de la antropología histórica. La obra de L. C. Álvarez Santaló \& M. J. Buxó \& S. Rodríguez Becerra (coords.), La religiosidad popular, Barcelona, 1989, 3 vols., representa en España, en cierta medida, la convergencia de antropólogos, historiadores y otros venidos de diversas áreas de conocimiento, en el interés y estudio acerca de la religiosidad popular.

${ }^{20}$ Por ejemplo, León Carlos Álvarez Santaló, «La Historia de la Cultura o el realismo de la «ficción»», en E. SARASA \& E. SERRANO (coords.), La Historia en el horizonte del año 2000, Revista de Historia Jerónimo Zurita 71 (1995), 143-177. 
Es ya un tópico historiográfico repetir que, desde Bataillon, la historia de la espiritualidad española en el siglo XVI se ha escrito «sub specie Erasmi» ${ }^{21}$. Sin embargo, el avance de los estudios en las últimas décadas, y muy especialmente los concernientes al fenómeno de las observancias religiosas desde fines del siglo XIV, el alumbradismo, y las distintas corrientes espirituales con sus diferentes plasmaciones literarias ${ }^{22}$, nos permiten plantear y construir la Historia espiritual del Quinientos de un modo mucho más completo, lógico y menos fragmentario de lo que pudo Bataillon en los años treinta en su siempre meritoria obra. Por ello, en este trabajo queremos contribuir a deshacer el antagonismo interioridad/exterioridad o, lo que es lo mismo, espiritualidad/religiosidad popular, que ha prevalecido en los estudios históricos sobre la religión cristiana en el siglo XVI. En este sentido, quiero desarrollar y matizar las oportunas tesis de M. Andrés criticando el obsoleto «pan-erasmismo» de cierta historiografía, replanteando el problema de la espiritualidad cristiana del Renacimiento y sus relaciones con todo aquello que se ha venido en llamar religiosidad popular ${ }^{23}$.

\section{ESPIRITUALIDAD Y RELIGIOSIDAD POPULAR: PRECISIÓN TERMINOLÓGICA}

Desde luego, antes de entrar en el estudio de las relaciones entre Espiritualidad y Religiosidad popular, es preciso aclarar los términos y saber nítidamente a qué nos referimos.

En un sentido histórico y filosófico ${ }^{24}$, el término «espiritualidad» haría referencia a un conjunto de vías, caminos, modos, para la puesta en relación del hombre visible con Dios invisible, en las que la oración sería el medio y la ocasión privilegiada para ese acercamiento-conocimiento-experimentación. En el caso de la espiritualidad cristiana, esa conexión personal entre el Hombre y Dios se funda en el amor, que parte de Dios, al cual responde libremente el hombre continuando en una dinámica personal de amor a Dios y al prójimo, y que conduce a éste hacia la unión con Dios.

Espiritualidad es conocimiento espiritual, es una experiencia y un gusto que hace saber-saborear al hombre sobre las cosas humanas, (los hombres y su

${ }^{21}$ M. Andrés Martín, Historia de la mística de la Edad de Oro en España y América, Madrid, 1994 , p. 282.

22 Un balance historiográfico sobre todas estas cuestiones y la espiritualidad castellana en general durante el Renacimiento se encuentra en R. M. PÉREZ GARCÍA, Sociología y lectura espiritual en la Castilla del Renacimiento, 1470-1560, Madrid, 2005, pp. 13-33.

${ }_{23}$ Véase M. Andrés MARTín, Historia de la mística de la Edad de Oro en España y América, Madrid, 1994, pp. 282, 284 y 287.

${ }^{24}$ Véase el siempre aclaratorio artículo de J. FERRATER MORA, «Mística», Diccionario de filosofía, Madrid, 1990, tomo III, pp. 2.234-2.236.

Hispania Sacra, LXI

124, julio-diciembre 2009, 587-620, ISSN: 0018-215-X 
mundo), y divinas, (Dios, el más allá, los ángeles, las almas). Conocimiento espiritual que se plantea como distinto al conocimiento propocionado por el estudio, es sabiduría frente a ciencia, es enseñanza de Dios en el y al hombre, acción-transformación del Espíritu Santo en su interior, frente a aprendizaje libresco, universitario, de humanos maestros. Sabiduría que es luz-iluminación en la oscuridad, ignorancia, de su corazón y su mente, oscuridad y tinieblas que no es capaz de barrer el estudio. La espiritualidad ha sido en la historia del cristianismo, y así se entendió y expresó claramente en el siglo XVI, una propuesta de otro modo de conocer que nace de la oración y el amor ${ }^{25}$.

El modo en que la teología espiritual se ha relacionado con la teología escolástica racionalista, dominante en la Iglesia desde el siglo XIII y sobre todo desde la segunda mitad del siglo XVI, y que prima el estudio, (las letras), sobre la experiencia, (el amor), constituye un capítulo fundamental de la Historia de la religión cristiana ${ }^{26}$.

No obstante, me he referido a la existencia de vías dentro de la espiritualidad, opciones diversas que dentro o fuera del marco general de una u otra religión son englobables dentro de la definición aquí presentada. La historiografía dedicada a la Historia espiritual de la España del siglo XVI se ha esforzado una y otra vez en crear múltiples clasificaciones para la multitud de expresiones, exposiciones, manifestaciones y realidades doctrinales y sociales de la espiritualidad de entonces ${ }^{27}$. No obstante, cualquier intento es siempre, por definición, esquematizante y empobrecedor.

Intentar definir el término «religiosidad popular» resulta bastante más complejo que en el caso de la espiritualidad. Y ello porque conlleva unas dosis mucho mayores de ambigüedad. Los intentos de los estudiosos por definir el término han sido múltiples. Así, religiosidad popular no sería sino el catolicismo popular, el resultado de la acción evangelizadora de la Iglesia llevada a cabo durante dos mil años respecto a las masas, inculturando en ellas el cristianismo ${ }^{28}$; o, en interpretación de cuño marxista, casi contraria, la religiosidad popular sería en realidad una religión popular, la religión de las clases subalternas, la religión del pueblo, religión de clase con inevitables contenidos

${ }^{25}$ Una explicación completa y pormenorizada del problema del conocimiento espiritual en los siglos XV y XVI en R. M. Pérez García, Sociología y lectura espiritual en la Castilla del Renacimiento, 1470-1560, Madrid, 2005, pp. 39-121.

${ }^{26}$ Sobre esta cuestión en la Europa de los siglos XV y XVI, véase R. M. PéreZ García: «Pensamiento teológico y movimientos espirituales en el siglo XVI», en A. L. CoRTÉs PeÑA, Historia del cristianismo, Madrid, 2006, tomo III, pp. 51-90.

${ }^{27}$ El último importante, en donde se refiere a los anteriores, es el de M. ANDRÉs MARTín, Historia de la mística de la Edad de Oro en España y América, Madrid, 1994, pp. 59-72.

${ }^{28}$ L. Maldonado, «La religiosidad popular», en L. C. Álvarez SANTALó \& M. J. Buxó \& S. RoDRÍGUEZ BECERRA (coords.), La religiosidad popular, Barcelona, 1989, vol. I, pp. 30-43. 
contestatarios $^{29}$; para otros no existe, no es nada, siendo el concepto de religiosidad popular con sus santuarios, procesiones, etc, simplemente, la religión católica ${ }^{30}$. También se ha planteado la cuestión en términos dicotómicos, contraponiendo la religiosidad popular a la oficial de la jerarquía eclesiástica, o considerando popular a la religiosidad del pueblo cristiano, los laicos, a diferencia de la religiosidad propugnada desde el clero-jerarquía. En esta última acepción se tendería a asociar a la religiosidad popular distintas supersticiones y elementos relacionados con el pensamiento primitivo y/o mágico.

En realidad, establecer una definición precisa de religiosidad popular pasa por considerar todas estas variantes. Partiendo de aquí, en este trabajo entenderemos por religiosidad popular un conjunto amplio de modos (vías), que dispone-utiliza de múltiples prácticas (romerías, peregrinaciones, procesiones, devociones a seres del más allá, exvotos, santuarios-lugares sagrados, candelas, velas, cordones, reliquias, nóminas, etc.) para entrar en relación con la divinidad y el más allá; repertorio ubicado en estratos sociales «populares» (con estructuras organizativas como hermandades y cofradías) y en una relación «compleja» con la jerarquía de la Iglesia.

LAS RELACIONES ENTRE ESPIRITUALIDAD Y RELIGIOSIDAD POPULAR EN LA PEDAGOGÍA PASTORAL FRANCISCANA

Desde fines del siglo XV y durante las primeras décadas del siglo XVI, la Orden franciscana experimenta una fulgurante expansión por Andalucía, al ritmo vertiginoso de nuevas y numerosas fundaciones ${ }^{31}$. Es expresión de la renovación observante y descalza que sacude la Orden y que deriva en un enorme impulso apostólico dirigido hacia todas las clases y grupos sociales, manifestado de múltiples modos. Uno de estos es el editorial. Según mis cálculos, entre 1470-1560 se publican 43 títulos de temática espiritual, que alcanzan 202 ediciones, debidos a escritores franciscanos. En este empeño apostólico, los franciscanos buscarán y crearán pedagogías populares en las que conviven la espiritualidad y la mística con las devociones más elementales en el marco

${ }^{29}$ L. Lombardi Satriani, «El hambre como derrota de Dios», en L. C. Álvarez Santaló \& M. J. Buxó \& S. Rodríguez Becerra (coords.), La religiosidad popular, Barcelona, 1989, vol. I, pp. 55-69.

${ }^{30}$ P. Córdoba Montoya, «Religiosidad popular: arqueología de una noción polémica», en L. C. Álvarez Santaló \& M. J. Buxó \& S. RodríGuez Becerra (coords.), La religiosidad popular, Barcelona, 1989, vol. I, pp. 70-81.

31 Véanse J. SÁnchez HERRERo, «Monjes y frailes. Religiosos y religiosas en Andalucía durante la Baja Edad Media», Actas del III Coloquio de Historia Medieval andaluza, Jaén, 1984, pp. 405-456 y J. M. MiURA ANDRADES, Frailes, monjas y conventos. Las órdenes mendicantes y la sociedad sevillana bajomedieval, Sevilla, 1998. Un resumen de los datos de estos trabajos en R. M. PÉrez García, Sociología y lectura espiritual en la Castilla del Renacimiento, 1470-1560, Madrid, 2005, p. 27.

Hispania Sacra, LXI

124, julio-diciembre 2009, 587-620, ISSN: 0018-215-X 
sacramental de la religión católica. Voluntad popularizadora que se manifiesta, en el campo de la literatura, en la utilización de comparaciones sencillas, de imágenes evocadoras tomadas de la vida cotidiana y perfectamente comprensibles para sensibilidades y entendimientos «populares» 32 . Ejemplo singular de esta labor lo tenemos en el franciscano andaluz fray Francisco de Osuna (c. 1492-c. 1541/1542), el mejor representante de la mística española del Renacimiento y autor de ocho libros en castellano (publicados entre 1527 y 1556) que nos servirán para penetrar en el terreno de las relaciones establecidas por la pastoral franciscana entre espiritualidad y religiosidad popular.

La concepción de la espiritualidad de fray Francisco de Osuna, tal y como él la diseñó en sus tres primeros Abecedarios espirituales («las tres partes del libro llamado Abecedario spiritual», impresos por vez primera entre 1527-1530), queda concisamente expresada en un párrafo del prólogo que pensó para ellos:

\begin{abstract}
«En las tres cosas y a dichas esta la perfecion del hombre que son meditar la passion del señor [objeto del Primer Abecedario]; y lo segundo casarse e tomar por muger la oracion [Segundo Abecedario]; lo tercero en venir a la bienauenturança de los viadores que es andar en via vnitiua de caridad vigilante con su Dios lo qual se alcança como fruto de las dos primeras [la teología mística o recogimiento, de la que trata el Tercer Abecedario]. Estas tres cosas tratan nuestros tres abecedarios...»33.
\end{abstract}

Meditación de la Pasión de Cristo y continua oración ocupan a las personas en la Creación (el mundo visible) y en la Humanidad de Cristo. Sin embargo, aunque ésta no impide al hombre alcanzar la Divinidad de Cristo, es muy provechosa para los que practican la mística-recogimiento ${ }^{34}$, y es la principal escala para subir a Dios, es «conveniente dejar algún tiempo la contemplación de la humanidad del Señor, para más libremente se ocupar por entero en la contemplación de la divinidad» $\mathrm{y}$ «hallamos escrito que conviene a los que se quieren allegar a la alta y pura contemplación dejar las criaturas y la sacra humanidad para subir más alto y recibir por entero la comunicación de las cosas puramente espirituales» es decir, invisibles y sin participación de corporeidad o materialidad ${ }^{35}$.

\footnotetext{
${ }^{32}$ R. M. PÉREZ GARCÍA, La imprenta y la literatura espiritual castellana en la España del Renacimiento, 1470-1560, Gijón, 2006, pp. 35 y 92-101.

${ }^{33}$ Francisco de Osuna, Primera parte del libro llamado Abecedario spiritual, Sevilla, 1528, f. $3 \mathrm{r}$.

34 «Es un aviso de harto prouecho a los que siguen el recogimiento pensar primero un rato en la sacra passion para que siendo por el tal pensamiento purgada nuestra fantasia con quietud puedan despues vacar sin ser molestados ... E lo primero que has de hazer es començar a meditar la passion del señor porque facilmente seran oxeadas con ella todas las vagueaciones. Si estando en el recogimiento no te dexan imaginaciones, no te podras mejor remediar que con la meditacion de la passion o representando a ti mesmo al señor apassionado» (Ibid, f. 18v).

35 Para todo este párrafo, Francisco de Osuna, Tercer Abecedario Espiritual, introducción y edición preparada por Saturnino López Santidrián, Madrid, 1998, pp. 90-91.
} 
Alcanzar la divinidad sin mezcla de otra cosa es el objeto de la teología mística, que Osuna también denomina recogimiento ${ }^{36}$ : es la vía negativa del conocer que aspira a conocer no conociendo, apagando las facultades ordinarias del conocimiento humano (sentidos y entendimiento) para despertar aquella otra (inteligencia) ${ }^{37}$ habitualmente dormida pero capaz de gozar de la unión con Dios ${ }^{38}$. Para Francisco de Osuna, el recogimiento es, desde luego, la vía religiosa más excelsa, por ser la que mayor comunión establece entre la persona y Dios ${ }^{39}$.

Para Osuna, la religión es búsqueda de un Dios al que se desea. En el tratado 18 del Tercer Abecedario «Nos amonesta buscar a Dios dentro en nosotros mismos, diciendo: Torna mucho sobre ti en silencio y esperanza». Pero junto a la búsqueda interior del recogimiento, en la que se renuncia a todo lo procedente de sentido y entendimiento mediante el silenciamiento de las potencias humanas, Osuna reconoce un amplio abanico de posibilidades en que se puede buscar a Dios:

«... unos buscan al Señor con los pastores en el pesebre por humildad y pobreza, otros con los reyes preguntan a los letrados siguiendo el estudio de la Sagrada Escritura, otros con nuestra Señora van al templo a lo buscar por oraciones y ofrendas; otros lo buscan en la cruz de la penitencia, con el buen ladrón; otros lo buscan peregrinando en romerías, como los dos discípulos a quien se mostró en forma de peregrino» ${ }^{40}$.

Multiplicidad de formas «buenas» de búsqueda, de las que la mejor es la interior del recogimiento («aunque todas las maneras ya dichas y otras semejables de buscar a Dios sean muy buenas, empero la que me parece mejor es buscarlo hombre en su corazón dentro de sí»41), pero que conducen todas a Dios:

«Estas y otras maneras suelen tener de buscar a Dios los que lo desean; el cual es tan cortés y benigno, que por quitar de trabajo a quien lo busca sale a recibirlo a todos por doquier que vayan a El...»42.

${ }^{36}$ Ibid, pp. 87 y 199.

${ }^{37}$ Sobre los nombres dados a esta «parte» del alma por los espirituales españoles de la época, R. M. PÉrez García, Sociología y lectura espiritual en la Castilla del Renacimiento, 1470-1560, Madrid, 2005, pp. 61-62.

38 Todo este proceso se halla descrito con detalle en ibid, pp. 39-63.

${ }^{39}$ Francisco de Osuna, Tercer Abecedario Espiritual, Madrid, 1998, pp. 197-200.

$40 \mathrm{Ibid}, \mathrm{p} .483$.

${ }^{41} \mathrm{Ibid}$, p. 483-484. La idea de la búsqueda interior de Dios es un elemento recurrente en los textos de Osuna. En Primer Abecedario también leemos: «O cosa maravillosa que no quiso el Señor mandarnos que lo buscassemos en Roma o en Jerusalen donde el conuerso y anduиo sino en nuestro coraçon que es cosa mas cercana a nosotros» (Francisco de Osuna, Primera parte del libro llamado Abecedario spiritual, Sevilla, 1528, f. 8r).

42 Francisco de Osuna, Tercer Abecedario Espiritual, Madrid, 1998, p. 483.

Hispania Sacra, LXI

124, julio-diciembre 2009, 587-620, ISSN: 0018-215-X 
Más aún, Osuna iguala el resultado que el hombre obtiene en sus distintas búsquedas: «En este buscar del Señor a que somos obligados hay gran diferencia entre los que lo buscan, por ser la manera de lo buscar diversa, aunque no lo sea la del hallar ni lo que hallan... $\rangle^{43}$. Por esos caminos el hombre encuentra a Dios: en el recogimiento interior, por la humildad y pobreza, estudiando la Escritura, y por otras vías que empiezan a señalar hacia el mundo «popular» de la relación con Dios: «por oraciones y ofrendas», «en la cruz de la penitencia», «peregrinando en romerías».

Este texto señala en un sentido que es importante recalcar: la espiritualidad (incluida la mística) franciscana bajomedieval y del Renacimiento, y a diferencia y por oposición a las espiritualidades erasmista y protestante (en su foco jerónimo de San Isidoro del Campo, junto a Sevilla), no parte de una radical oposición entre carne y espíritu, entre creado e increado, entre visible e invisible. Muy al contrario, integra ambos segmentos de la Realidad en un todo continuo que el hombre debe recorrer subiendo y bajando «por la escalera, que es la orden de las cosas criadas»: «Suben al conocimiento del Criador y abajan al conocimiento de sí mismos; sólo Dios está inmutable a lo más alto del escale$r a »^{44}$. Esta concepción religiosa está en el origen de una especial sensibilidad y valoración de las múltiples manifestaciones «sensibles» de la fe y devoción populares, expresiones que los mismos frailes menores van a respaldar e, incluso, compartir.

En el caso del místico Francisco de Osuna, conocemos su interés por determinados elementos de lo que se podría calificar de religiosidad externa:

1) Las reliquias de los santos, para cuyo conocimiento y veneración no duda en viajar y peregrinar. En su juventud, antes de entrar en religión, peregrinó a Santiago acompañado de un conocido ${ }^{45}$. Años más tarde, en una de las fases (hacia 1534-1536), en una de las fases de su viaje por Europa aprovecha para visitar los grandes centros de peregrinación de Aquisgrán y Colonia y conocer de primera mano reliquias célebres en toda la Cristiandad: «... yo quando yиa a Colonia a visitar las onze mil virgines y los tres reyes magos, passe por una ciudad que se dize Aquisgrano, donde el emperador rescibe la primera corona, porque alli sin otras sanctissimas reliquias yo no quisiera auer dexado de ver por tres años de vida. Finalmente que alli esta entre otras las del bienauenturado Carlomagno, capitan y señor que fue de los doze pares, y emperador romano, cuyo huesso dende el codo a la mano se muestra alli, donde claramente pa-

\footnotetext{
43 Idem.

${ }^{44}$ Ambas citas en ibid, p. 89.

${ }^{45}$ Francisco de OsunA, Quinta parte del abecedario espiritual, Burgos, 1542, f. 125v: «Acuerdome que siendo yo moço seglar yua con otro compañero a Sanctiago, y ...».
} 
resce que su codo excede un gran palmo al de qualquiera otro» ${ }^{46}$. Cuando regresa a España a fines de 1536 o principios de 1537, arribando posiblemente a algún puerto del norte de la Península, se acerca a Pontevedra para venerar el sepulcro del predicador Navarrete, muerto en 1528 con fama de hacedor de milagros ${ }^{47}$. Osuna se refiere al buen olor de los cuerpos de los santos («aun acá en la tierra huelen mucho los cuerpos santos»), señal del futuro olor de los cuerpos glorificados ${ }^{48}$, y a la incorrupción de los cuerpos de los santos en sus sepulcros como merced de Dios ${ }^{49}$, algo que se relaciona con la consideración positiva del sepulcro que guarda los huesos de un santo como lugar privilegiado de oración y de mayor proximidad a Dios ${ }^{50}$. Para los partos, Osuna recomienda a los esposos que busquen «algunas reliquias que entonces tenga consigo su muger ${ }^{51}$. Más aún, junto al interés por las reliquias de los santos difuntos, Francisco de Osuna se interesó en vida por conseguir objetos, (reliquias), de personas vivas de su tiempo con fama de santidad. Así, cuando en 1523 su discípulo Olivares, de Pastrana, regresa de Valladolid adonde ha viajado para conocer a la beata Francisca Hernández, más tarde condenada por la Inquisición, regala a Osuna, entonces residente en el convento de La Salceda, unas cuentas que ésta le ha regalado. Osuna, como muchos franciscanos de la época, se sienten atraidos por cuentas de mujeres reputadas de santidad, colaborando, incluso, a difundir la devoción a ellas ${ }^{52}$.

No obstante, es importante aclarar que, al tiempo que Osuna participa personalmente de estas devociones, las ataca cuando se convierten en sustitutas de la práctica sacramental de la Iglesia. Critica duramente a los que van «a visitar santuarios y buscar peligrosas devociones, caminas por ver sanctos vivos y muertos» viajando incluso a Roma, Santiago o Jerusalén, y dejan a un lado la

46 Ibid, f. $175 \mathrm{v}$

${ }^{47}$ Francisco de OsunA, Tercer Abecedario Espiritual, Madrid, 1998, p. 25; Francisco de OsunA, Quinta parte del abecedario espiritual, Burgos, 1542, f. 137r. Sobre Navarrete, véase Pedro de SALAZAR, Coronica y Historia de la Fvndacion y Progresso de la Provincia de Castilla..., Madrid, 1612, pp. 149-154.

${ }^{48}$ Francisco de Osuna, Norte de los estados, Burgos, 1550, f. 11v.

49 Ibid, f. $12 \mathrm{v}$.

${ }^{50}$ En el planto de Villaseñor por su esposa muerta, Osuna pone en boca de su personaje dice que «seré mas presto oydo quando orare sobre tu sepulcro, que si orare sobre los huesos de algun santo» (Francisco de OsunA, Norte de los estados, Burgos, 1550, f. 136r). Y cuando recomienda pensar en la Pasión de Cristo, con objeto de alejar del fiel la tibieza recomienda «que te pongas a meditar en el lugar mas reuerente que hallares para que del seas prouocado, assi como en la capilla delante del sacramento o encima de alguna sepultura de alguna persona de buena fama o cerca de algunas reliquias o cuerpo sancto» (Francisco de OsunA, Primera parte del libro llamado Abecedario spiritual, Sevilla, 1528, f. 46r)

${ }^{51}$ Francisco de Osuna, Norte de los estados, Burgos, 1550, f. 87v.

52 R. M. PÉrez GARcía, Sociología y lectura espiritual en la Castilla del Renacimiento, 14701560, Madrid, 2005, p. 185.

Hispania Sacra, LXI

124, julio-diciembre 2009, 587-620, ISSN: 0018-215-X 
Eucaristía y la comunión ${ }^{53}$. Se queja de los que van a la iglesia el día de determinados santos a las misas de estos («la misa de sant Juan o de otro santo») y comulgan básicamente "por honrar los santos» ${ }^{54}$, y de aquellos que van en romería a ciertas iglesias, ayunan durante días o se disciplinan y dan doscientos azotes, pero no limpian su alma con la confesión ${ }^{55}$.

Asimismo, aligera a los casados de votos, promesas y peregrinaciones cuando estas pueden enturbiar la convivencia matrimonial o poner en peligro el sostenimiento económico de la familia. Al marido que le cuenta que su mujer «me importuna que la lleve a Guadalupe que tiene alla prometidas novenas... y [se dedica a] andar muchas estaciones y darse a devoterias y que presume de santa», le aconseja que le cierra la puerta y que «quando sea monja podrá hazer como monja, agora que es casada ayase como casada»56. Del mismo modo, arremete contra las «supersticiones» del «vulgo ignorante y mugercillas inquietas», cuando encuentra que éstas les interesan más que la Pasión: ensalmadores, saludadores, santiguaderas, «romerias y velas dañosas, y con numeros de dias en tal o tal tiempo y a tales horas ... y palabras dichas en lenguaje que no pueden ser entendidas, y con otras señales y vanas observaciones inventadas por el demonio y los suyos para estorvar la devocion christiana de la Pasion de Christo, remedio de todos nuestros males» ${ }^{57}$.

2) Devociones para determinadas situaciones de la vida: enfermedad, esterilidad, parto. Contra la falta de hijos, enseña la devoción del envío de una sábana hilada al Santo Sepulcro de Jerusalén ${ }^{58}$, o propone tomar devoción a San Antonio de Padua ofreciéndole al santo diversos votos (celebrar su fiesta, ayunar su vigilia, llamar Antonio al niño) $)^{59}$ para conseguir su mediación a fin de tener un hijo. Para ayudar a las mujeres en parto, explica, y propone extender, la devo-

\footnotetext{
53 Francisco de OsunA, Gracioso combite de las gracias del sancto sacramento del altar, Burgos, 1537, f. $12 \mathrm{v}$.

${ }^{54}$ Ibid, f. 16v-17r.

55 Ibid, f. 18 r.

56 Francisco de OsunA, Norte de los estados, Burgos, 1550, f. 127v.

${ }^{57}$ Francisco de Osuna, Primera parte del libro llamado Abecedario spiritual, Sevilla, 1528, f. $5 \mathrm{v}$.

58 «... esta muy esperimentada devocion que te dire, y es que hagas a tu muger hilar una tela de muy buen lienço, y de alli haz una sauana muy hermosa, y embiala al sepulcro sancto de Jerusalem para lo cubrir, y darte a el Señor hijos. Esta devocion hizo la primera condesa de Oropesa, y despues de embiada la sauana pario tantos hijos que estuuo en puntos de embiar por la sauana, pensando que cessaria de parir. Esta deuocion hizo tmbien la reyna catolica doña Isabel que no paria sino hijas, y en embiando la sauana hilada de su mano pario el principe don Juan» (Francisco de OsunA, Norte de los estados, Burgos, 1550, f. 66v).

59 «Allende de los remedios ya dichos ay otro muy aproudo y es que el marido y la muger tomen deuocion con sant Antonio de Padua, y prometan de le hazer su fiesta cada año, y ayunalle su vigilia, y que al niño deseado llamaran Antonio, y nunca le vedaran cosa que sea del servicio de Dios. Los casados que este voto fizieren y lo guardaren crean que les dara Dios hijos de bendicion» (ibid, f. 66v).
} 
ción existente de tocar nueve veces las campanas que avisan a las gentes para que recen nueve Avemarías al parto de la Virgen ${ }^{60}$. No debe pasarse por alto el recurso a un número determinado, el nueve, en clara relación con los nueve meses del embarazo, y que Osuna asume, admitiendo así, claramente ya, una componente de matriz mágica. Indicio de que en su apostolado cotidiano a las gentes simples, los franciscanos admitirán estos elementos. Ello, siempre, en el esfuerzo por ordenar la devoción en una jerarquía ortodoxa, subordinándola a los sacramentos: "Si suelen los hombres buscar devociones y palabras sanctas con que sanen, que cosa mas devota pueden hazer quando estan enfermos que confesar y comulgar por esta intencion a fin de sanar y dar gloria a Dios» ${ }^{61}$.

\section{LA ORdEN DE SAN Francisco y LA PASIÓN DE CRISTO}

\section{La Pasión en la espiritualidad franciscana}

La meditación de la vida de Cristo había constituido desde los orígenes del franciscanismo la fuente primordial de su espiritualidad. En especial, y partiendo del ejemplo del propio San Francisco de Asís, la Encarnación y la Pasión fueron los momentos preferidos, intensa y abrumadoramente preferidos ${ }^{62}$. Cuando desde fines del siglo XIV se desarrollan en la Península Ibérica diversos movimientos de reforma de la Orden en un sentido espiritual y de estricta pobreza y guarda de la regla de San Francisco, se sigue constatando la misma

60 «En los lugares que usan de mas christiandad tienen por devocion que quando alguna muger esta de parto, embian a la yglesia que den nueve golpes a una campana grande para que todos conozcan como una muger esta en aquel trabajo, y rezen nueve Ave Marias, al parto beatissimo de nuestra señora, que tenga por bien de ayudalle. En los lugares do no ay esta costumbre, hara mucho servicio al señor el que la pusiere, porque obra es de gran misericordia espiritual orar por la persona que se vee en carcel de tanta necesidad y visitalla con la buena obra de la oracion» (ibid, f. 86r)

61 Ibid, f. $131 \mathrm{r}$.

${ }^{62}$ Como leemos en las Florecillas de San Francisco: «El principal y sumo anhelo de San Francisco se cifraba en observar en todo y por todo el santo Evangelio y seguir fervorosa y perfectísimamente la doctrina y los ejemplos de nuestro Señor Jesucristo. Meditaba continuamente sus palabras y veneraba devotísimamente sus obras; pero sobre todo la humildad de la Encarnación y la caridad de la Pasión los tenía tan presentes que apenas quería pensar en otra cosa» (Florecillas de San Francisco, Bogotá, 1985, p. 356). Y su primitivo biógrafo Tomás de Celano, al tratar en su Vida segunda ( $2^{\mathrm{a}}$ parte, cap. XXIII) de las devociones particulares del Santo, escribe que «celebraba con mayor regocijo que otras solemnidades la Natividad del Niño Jesús, asegurando que ella era la fiesta de las fiestas...», y, al referirse a su devoción a la cruz, el cronista afirma no hallar palabras para expresarla y pregunta exclamando: «...¿quién podrá expresar, quién entender siquiera cómo se gloriaba nuestro Santo únicamente en la cruz del Señor? ¡Sólo le será dado conocerlo a quien fue dado experimentarlo!» (Escritos completos de San Francisco de Asís y biografías de su época, ed. de J. de Legísima \& L. Gómez Canedo, Madrid, 1945, pp. 504 y 506).

Hispania Sacra, LXI

124, julio-diciembre 2009, 587-620, ISSN: 0018-215-X 
predilección por la Pasión: así, entre los villacrecianos castellanos, que probablemente arribaron al ámbito sevillano (en San Francisco del Monte en Villaverde del Río) en las primeras décadas del siglo XV63. De ellos escribe que fray Lope de Salazar y Salinas (muerto en 1463) que «su contemplación e oración era en la pasión e vida del su dulce esposo Jesucristo, según la hora e horas de la oración, ordenándola por la doctrina de San Bernardo, e de San Anselmo», Pasión de Cristo que acostumbraban más llorarla que rezarla, con el objeto de mover los sentimientos del fraile y «despertar los tibios en la oración» ${ }^{64}$. También, y ya en el ámbito andaluz, en la Custodia, luego Provincia, de los Ángeles, a fines del siglo XV, en la que su fundador fray Juan de la Puebla daba muestras sobradas de su voluntad de imitación de Cristo en la Pasión: «Estando la comunidad comiendo en el refectorio, solía entrar el venerable Padre, y Maestro Fray Juan de la Puebla, desnudo la mitad del cuerpo por la parte superior, vestido el pecho con çarças, ceñida la cabeça con una corona de espinas, açotandose crudamente, para imitar a Christo en su desnudez, y açotes, y corona de espinas, que padecio por el hombre», y él y sus frailes «otras vezes entrauan en comunidad con cruzes pesadas sobre sus ombros, y sogas a la garganta $^{65}$, pidiendo por amor de Dios unos a otros, ... que fuessen publicando sus defectos, y vertiendo copiosas lagrimas, pedian al sieruo de Dios su Prelado, les diese penitencia de ellos» ${ }^{66}$. El cronista Guadalupe plasma sonoramente el resultado de tales prácticas en las sierras que rodeaban a Santa María de los Ángeles: «O santas, y felices montañas, cuyo silencio se veia rompido con el gemir y estruendo de asperas disciplinas» 67.

Al mismo tiempo, en el franciscanismo reformista y descalzo de la época, encontramos la práctica penitencial de la disciplina y la autoflagelación, adop-

\footnotetext{
${ }^{63}$ Rafael M. PÉREZ García, «La biblioteca del convento de San Francisco del Monte de Villaverde del Río: libros de autor franciscano (1646)», Archivo hispalense 256-257 (2001), 134-135.

${ }^{64}$ Introducción a los orígenes de la Observancia en España. Las reformas en los siglos XIV y XV, Archivo Iberoamericano 17 (1957), 645, 646 y 649, las dos citas en la primera y última de estas páginas.

${ }^{65}$ Hacer penitencia con una soga al cuello para acusarse a sí mismo como pecador ante los demás es un comportamiento que imita un hecho de la vida de San Francisco, recogido por las biografías más antiguas conservadas (Celano y San Buenaventura), y que se acabó convirtiendo en un motivo iconográfico (M. D. Fraga SAMPEDRO, «Imagen, predicación y exempla. La predicación de San Francisco con la soga al cuello», en M del Mar Graña CID (ed.): El franciscanismo en la Península Ibérica. Balance y perspectivas, Barcelona, 2005, p. 901-904).

${ }^{66}$ Andrés de Guadalupe, Historia de la Santa Provincia de los Ángeles, de la Regular Observancia y Orden de Nuestro Seráfico Padre San Francisco, Madrid, 1662, pp. 46-47. No en vano escribe Lejarza que las constituciones angelinas «recuerdan mucho el espiritu austero de las fundaciones villacrecianas» (Fidel de LEJARZA, «Orígenes de la descalcez franciscana», Archivo Iberoamericano 22 (1962), 29).

${ }^{67}$ Andrés de Guadalupe, Historia de la Santa Provincia de los Ángeles, de la Regular Observancia y Orden de Nuestro Seráfico Padre San Francisco, Madrid, 1662, p. 47.
} 
tada por la Orden desde sus orígenes. En la Provincia de los Ángeles, la práctica era de las más suaves entre lo que era y sería habitual entre los descalzos y en las Constituciones recoletas de 1523: sólo se impone el ejercicio de la disciplina tres días a la semana, lunes, miércoles y viernes ${ }^{68}$, si bien éstas relajaban otras constituciones anteriores de la Custodia de los Ángeles elaboradas también por el propio fray Juan de la Puebla ${ }^{69}$. Disciplina que tiene una componente fundamental y constitutiva de memoria e imitación personal de la Pasión de Cristo. De hecho, los franciscanos llegaron a interpretar la estigmatización de San Francisco como un acto de Dios «para que por este medio los hombres se acordasen más de su bendita Pasión» ${ }^{70}$. A este respecto es muy significativo el hecho de que a fines del siglo XV y primeras décadas del siglo XVI culmina un proceso de simplificación de la iconografía de San Francisco de Asís que la reduce básicamente a la escena de la impresión de las llagas, tendiendo además a convertir al ángel en Cristo crucificado, de modo que se asimilaba a San Francisco con Cristo llagado y crucificado ${ }^{71}$. Esta iconografía centrada principalmente en el episodio de la Estigmatización se extiende por Andalucía desde el siglo XV72.

La devoción por la Pasión está engastada totalmente en la espiritualidad franciscana que la considera como la vía excelente que permite saltar a la per-

68 A. URIBE, «Espiritualidad de la descalcez franciscana», Archivo Iberoamericano 22 (1962), 159160, que remite a Andrés de GuAdalupe, Historia de la Santa Provincia de los Ángeles, de la Regular Observancia y Orden de Nuestro Seráfico Padre San Francisco, Madrid, 1662, p. 142: «... que todo el año se tuuiesse diciplina comun los tres dias de la semana, Lunes, Miercoles y Viernes; y despues de auerla tenido, puestos los Religiosos en cruz, digan tres Credos en memoria de las tres horas, que Christo nuestro señor estuuo en la cruz ... que los hermanos, assi Legos, como Coristas, que no tengan siete años de habito, y los demas Religiosos Sacerdotes, que estuuieren debaxo de la mano del Maestro, se disciplinen en el refectorio todos los Viernes del año; y en tiempo de Adviento, y Quaresma hagan la mesma disciplina, y coman en tierra los tres dias señalados de la semana». Para la mortificación y disciplina entre las terciarias claustrales en la época, A. ABAD PÉREZ, «Monasterios de contemplativas de la Tercera Orden Regular Franciscana en España», I Congreso Internacional del Monacato Femenino en España, Portugal y América (1492-1992), León, 1993, tomo II, p. 153.

${ }^{69}$ Andrés de Guadalupe, Historia de la Santa Provincia de los Ángeles, de la Regular Observancia y Orden de Nuestro Seráfico Padre San Francisco, Madrid, 1662, pp. 44-45: «... la diciplina se tenga todo el año con sus Psalmos y oraciones despues de Maitines, saluo los Domingos, y fiestas dobles».

${ }^{70}$ Francisco de Osuna, Primera parte del libro llamado Abecedario spiritual, Sevilla, 1528, f. 5 r. Sobre San Francisco como la imagen más perfecta de Cristo, J. A. SÁNCHEZ LóPEZ, «Iconografía franciscana en Andalucía: los temas y su proyección artística», en M. PELÁEz DEL RosAL (dir.), El franciscanismo en Andalucía. I Curso de Verano, Córdoba, 1997, p. 259.

71 J. J. Vélez Chauri \& P. L. Echeverría GoÑI, Representaciones de San Francisco de Asís, Donostia, 1991, p. 22-28.

72 J. M. MEdianero Hernández, «Iconografía de San Francisco en la pintura gótica andaluza (siglos XIII-XV)», M. Peláez del Rosal (dir.), El franciscanismo en Andalucia. II Curso de Verano, Córdoba, 1998, p. 151.

Hispania Sacra, LXI

124, julio-diciembre 2009, 587-620, ISSN: 0018-215-X 
sona orante (dedicada a la meditación y contemplación) desde la Humanidad de Cristo a su divinidad. El Primer Abecedario Espiritual de Francisco de Osuna que, según reza la portada de su primera edición (Sevilla, 1528) «trata de las circunstancias de la sagrada passion del hijo de dios», es un excelente exponente de esta espiritualidad. Además, Osuna, aunque promete ofrecer un libro «distinto» sobre el tema, utiliza continuamente los relatos medievales tradicionales sobre la Pasión, valiéndose de las principales fuentes, franciscanas o no ${ }^{73}$. En él, Osuna incita al cristiano a pensar y meditar continuamente, en todo momento y ocasión, alguno de los misterios de la Pasión, «siquiera un rato en el dia no dexes de pensar en la bendita passion» 74 , «determina con rigor de meditar cierto tiempo en tal ora y aquel firme proposito te valdra mucho» ${ }^{75}$. Se trata de recrear fervorosa, emocionalmente, la Pasión, llorando e intentando sentir lo mismo que sintió Cristo en su Pasión: un Cristo que sufrió en todos sus miembros y en todo su ser, que padeció todo lo que pudo ${ }^{76}$ y culminó así una vida de sufrimiento ( toda la vida del Señor fue cruz y tormento» ${ }^{77}$ ), sintiendo un enorme dolor corporal en la cruz, mayor que el de un parto ${ }^{78}$, derramando hasta la última gota de su sangre ${ }^{79}$, llegando incluso a llorar sangre hasta quedar todos sus miembros cubiertos por ella en el huerto de Getsemaní ${ }^{80}$, no dejando sin

${ }^{73}$ Fidel de Ros muestra diversas dependencias del texto de Osuna respecto de la Schala passionis de Jean Mombaer, abad de Livry, y señala como otras muy probables fuentes las Meditaciones de la vida de Jesucristo atribuidas a San Buenaventura, el Arbor de la vida crucificada de Jesús del espiritual franciscano bajomedieval Ubertino de Casale, y la Vida de Cristo del cartujo Ludolfo de Sajonia (F. de Ros, Un maitre de Sainte Thérèse: Le Père François d'Osuna. Sa vie, son oeuvre, sa doctrine spirituelle, París, 1936, pp. 283-288). Sabemos que la obra de Ubertino fue traducida al castellano en tiempos y por orden de Isabel la Católica (Biblioteca Universitaria de Salamanca, manuscrito 371), y que al cartujano Ludolfo lo tradujo fray Ambrosio Montesino y circulaba impreso desde 1502-1503. También sobre las vidas medievales de Cristo y en el tránsito al siglo XVI, es muy interesante Dorothy S. Vivian, «La Passión trobada, de Diego de San Pedro, y sus relaciones con el drama medieval de la Pasión», Anuario de Estudios Medievales 1 (1964), 451-470. Un ejemplo de relato sobre una escena de la Pasión del Primer Abecedario tomada por Osuna de fuentes anteriores y presente también en otras obras literarias de la época, en R. M. PÉREz GARCíA, Sociología y lectura espiritual en la Castilla del Renacimiento, 1470-1560, Madrid, 2005, p. 405. Últimamente se ha publicado una edición del Primer Abecedario, en cuyo estudio introductorio también se hace mención a las fuentes del mismo (J. J. MORCILlo PÉREZ, «Introducción», Francisco de OsunA, Primer Abecedario Espiritual, Madrid, 2004, pp. LXIX-LXX).

${ }^{74}$ Francisco de Osuna, Primera parte del libro llamado Abecedario spiritual, Sevilla, 1528, f. 14r.

75 Ibid, f. 45v.

76 Ibid, tr. V, cap. 2.

77 Ibid, f. 30v.

$78 \mathrm{Ibid}$, tr. IV, caps. 1 y 2 . Aspirar a sentir un dolor mayor que el del parto durante la meditación de la Pasión de Cristo. He aquí otro lugar común religioso vinculado a la devoción a la Pasión heredado de la Edad Media. Huizinga recuerda cómo la francesa Santa Colette sufría, al leer la Pasión, más que ninguna mujer en los dolores del parto (J. HuIZINGA, El otoño de la Edad Media, Madrid, 1990, p. 269).

${ }^{79}$ Francisco de Osuna, Primera parte del libro llamado Abecedario spiritual, Sevilla, 1528, tr. VI, 1.

${ }^{80} \mathrm{Ibid}, \mathrm{tr} . \mathrm{X}$. 
colmar ningún posible sufrimiento humano, incluidas la deshonra, la infamia y la vergüenza de la desnudez pública ${ }^{81}$. Todo esto tenía un fin principal: «todos sus dolores fueron por vernos nacidos a nueva vida de gracia» ${ }^{22}$. Así, la meditación de la Pasión de Cristo, dice Osuna, «es el colirio y uncion con que deues untar los ojos de tu anima para que veas... mediante la meditacion se alcança el dulce gusto de la passion» ${ }^{83}$.

El fiel debe considerar cada aspecto de la Pasión, pormenorizadamente expuestos en las 324 páginas en $4^{\circ}$ del Primer Abecedario, y especialmente debe recorrer con su pensamiento la figura de Cristo, «el devoto puede meditar como el Señor padecio todos sus miembros y divino cuerpo» ${ }^{84}$. El tratado 16 contiene, por ejemplo, «una devota contemplacion de los miembros del Señor», llevando al lector a repasar pausadamente cada uno de los miembros de Cristo en la cruz ${ }^{85}$ : la cabeza y cabellos del Señor, sus ojos y nariz, su «preciosa boca» y dientes, «la lengua del Salvador», sus mejillas, faz y barbas, su cuello, hombros, brazos, manos, pecho, el «sagrado costado», son explicados en plásticas descripciones que ocupan páginas y páginas que recalcan la brutalidad del sufrimiento de Cristo y que pretenden despertar las emociones del lector.

Las descripciones contenidas a cada paso en Primer Abecedario son verdaderas pinturas de los distintos momentos de la Pasión. Al reflexionar sobre las palabras de Pilato «Ecce homo», recorre el cuerpo triturado de Cristo, comparándolo, en una imagen perfectamente comprensible para un andaluz de la época, con un toro:

«... pues que a los toros echan puas y dessuellan los animales, tus açotes señor peores fueron quel dessollar al carnero, y tus espinas se dizen ser como las puas que ponen en las garrochas para correr los toros, saluo que a ellos se las reparten por todo el cuerpo, y a ti te las ponen muy hincadas en la cabeça. A los toros corren sueltos y a ti muy atado te acossan y cansan con los multiplicados tormentos, el toro buelue por si, e no da a todos lugar que lo hieran mas tu no abres tu boca ni desechas a nadie» ${ }^{86}$.

\footnotetext{
$81 \mathrm{Ibid}$, tr. XIV.
}

82 Ibid, f. 26v.

83 Ibid, f. $17 \mathrm{v}$.

${ }^{84}$ Ibid, f. 28 r.

${ }^{85}$ El repaso meditado y sucesivo de cada uno de los miembros de Cristo es una práctica que procede de la Edad Media. Así, lo encontramos, por ejemplo, en las Revelaciones de Santa Isabel de Hungría, de las que hayamos reflejo en el Floreto de San Francisco, impreso en Sevilla en 1492, y en diversos textos franciscanos del siglo XV (J. M. Arcelus Ulibarrena, Floreto de San Francisco, Madrid, 1998, pp. 812 y 288-291).

${ }^{86}$ Francisco de OsunA, Primera parte del libro llamado Abecedario spiritual, Sevilla, 1528, f. 74v. 


\section{La descripción de la flagelación, con el cuerpo de Cristo cubierto de sangre,} no tiene desperdicio:

«... los açotes crueles dissiparon todo su sancto cuerpo tornándolo peor que de leproso hecho manantial de sangre en tal manera que no auia de pies a cabeça en su sancto cuerpo parte de la qual con mil dolores no corriesse y manasse sangre, peor que sajado lo pararon seys verdugos de dos en dos: los primeros con unas vergas muy espinosas, los segundos con unos cordeles nudosos y en los nudos estauan unas puas muy agudas, estos cansados sucedieron los terceros con unas cadenillas a manera de disciplina que tiene al cabo unas rodajuelas de puntas torcidas al contrario unas de otras que rasgauan su preciosa carne y dissipauan su cuerpo. Allí se multiplicaba llaga sobre llaga, roncha sobre roncha, y los cardenales unos sobre otros espesos hasta ennegrecer y magular su preciosa carne que era lástima grande de ver. ;O que escozimiento y dolor quando todo dessollado su cuerpo se vistio la purpura aspera que si colorada no fuera la sangre bastara para la teñir. El rastro dexaua por donde yua porque el regajal de la sangre no cessaua de correr, sus pisadas eran claramente señaladas del cruor. Cada passo que daua le era la muerte en el qual se mouian todas sus venas que auian quedado rasgadas de los açotes y de nueuo abiertas tornauan a manar. Lastima grande era verlo...»87.

\section{Las escenas de la crucifixión son igualmente plásticas:}

- «... como enclauassen con gruesos clavos en distantes agujeros las benditas manos del señor, y como estando con cordeles estiradas, los pies no alcançassen al lugar donde auian señalado, leuantaron en alto la pesada cruz y dexaronla caer ... para que estando el señor alto pudiessen tirar de los pies mejor para que alcançassen, y esto hecho ató el uno de los sayones un cordel a los sanctos pies y otro puesto en una escalera tomó un martillo y un gruesso clavo mas que los otros, y estándolo hincandolo en los sagrados pies, por la sangre que dellos corria resualosele el martillo de las manos...»88.

- «Lo que estas manos padecieron es cosa manifiesta assí en ser con rezios cordeles atadas como en ser con gruessos clauos enclauadas en la cruz, y tan gruessos que el dedo grossero pudiera caber por la señal y abertura que dexaron. O qué increíble dolor sería abrirse los huessos de las manos para que el gruesso clauo passasse y lleuar consigo parte de essa poca carne que las manos tenían y ser los neruios todos encogidos y los dedos juntarse todos con el clauo yéndose tras el principal dolor, y allégase a esto el dolor que se podía añadir de ser según se dixo los braços tan estirados el qual no fue pequeño, y también la pesadumbre del cuerpo que de solas las manos estaua colgada, esto todo añadía dolor y hazía mayores los agujeros, y aun maravíllome como no se abrió y rasgó del todo la mano, lo vno por ser tan estirados los braços, lo otro por apesgar todo el cuerpo de solas las manos enclauadas» ${ }^{89}$.

Finalmente, Osuna, con el fin de conseguir la plena identificación del lectormeditador con Cristo, y para hacerle entender mejor qué fue la Pasión, le pro-

\footnotetext{
${ }^{87}$ Ibid, f. 41r.

${ }^{88}$ Ibid, f. 22v.

${ }^{89}$ Ibid, f. $102 \mathrm{v}$.
} 
pone la autoflagelación: «toma una açote y disciplinate para que sientas en ti lo que sintiria el señor en sus passiones e tormentos» ${ }^{90}$.

En el esquema sobre la Pasión del Primer Abecedario, la Sangre de Cristo ocupa un lugar importante. Desde luego, este hecho no es ajeno a la importante controversia teológica habida años antes, durante el pontificado de Pío II, 14581464, sobre la Sangre de Cristo ${ }^{91}$. Así, el tratado sexto del Primer Abecedario «habla de la mucha sangre que el señor por nosotros derramó», y el tratado 17 «habla de la sangre del Señor», analizando sus propiedades y las consecuencias espirituales de su derramamiento, y fundamentalmente enseñar que se vertió «para que limpie nuestras conciencias y las emblazquezca»92, "porque con inmensa caridad desseaua con su limpia sangre limpiar nuestros pecados, y no descansó el amor hasta que se mostró por la obra»93.

En definitiva, la sangre derramada de Cristo es signo bautismal del nacimiento del hombre a la vida espiritual con la condición de hijo de Dios, es decir, resumen de la obra salvadora de Cristo. Francisco de Osuna lo expresa así: «Hijo suyo llama al que da a comer su sangre, porque para hazerle hijo suyo se la $d a »^{94}$.

La convicción profunda del franciscanismo de lo importante y enormemente dramático de la tragedia de la Pasión, de dimensiones cósmicas al tratar de algo tan enorme como el juicio, tortura y asesinato del Hijo de Dios, y liberación de la Humanidad del yugo del pecado, provocará decididas iniciativas de extensión del culto y reverencia a la Pasión y a cada uno de sus elementos. Estas iniciativas tendrán un fuerte carácter imitador de la figura de Cristo, y una finalidad marcadamente penitencial.

\section{Franciscanos y cofradías de la Vera Cruz}

En relación con estas teología y espiritualidad franciscanas, así como con la facilidad y fuerza con que los frailes menores conectan con los sectores seglares de la sociedad ${ }^{95}$, brotan y se empiezan a gestar desde el siglo XV las cofra-

${ }^{90}$ Ibid, f. 46r.

${ }^{91}$ C. Ros (dir.), Historia de la Iglesia de Sevilla, Sevilla, 1992, p. 343; B. LlorCa \& R. GARCía VILlosladA, Historia de la Iglesia Católica, Madrid, 1987, tomo III, p. 402.

92 Francisco de Osuna, Primera parte del libro llamado Abecedario spiritual, Sevilla, 1528, f. 104v.

93 Ibid, f. 105 r.

94 Ibid, f. 112 v.

95 José García Oro, «El franciscano hispano de la Edad Media», Verdad y Vida 178-179 (1987), 245-247.

Hispania Sacra, LXI

124, julio-diciembre 2009, 587-620, ISSN: 0018-215-X 
días de la Vera Cruz, de la Sangre o de Disciplinantes, con el pleno carácter de cofradías de penitencia ya a fines del siglo XV y comienzos del XVI ${ }^{96}$.

Es sobradamente conocido que el nacimiento de estas cofradías de la Vera Cruz está vinculado a la acción de los franciscanos, que difunden este culto ${ }^{97}$. El planteamiento religioso de estas cofradías, tal y como queda consignado en sus reglas, es netamente penitencial ${ }^{98}$ y claramente orientado a no convertir en inútil la muerte, con el vertimiento de su Sangre, de Cristo en la Cruz. En tanto que el hombre hace penitencia del modo «correcto», el sacrificio autoinmolatorio de Cristo sirve para procurarle la purificación de sus pecados y, por tanto, su salvación. En caso contrario, de nada habría servido la muerte de Cristo. Ahí cobran sentido las palabras que leemos en la Regla de 1538 de la Cofradía de la santa Vera Cruz de Sevilla, establecida "a honra y reuerencia de la Sanctísima Cruz y Sangre de Cristo» y "situada en el conbento del Seráfico Padre San Francisco en esta ciudad de Sevilla» ${ }^{99}$.

«... nos los cofrades y hermanos de la dicha Cofradía, deseando ... mostrar alas de el deseo que tenemos de seruir a Dios nuestro Señor por tan supremo bien y soberano beneficio que nos a hecho y haze en elegirnos para guarda y proteción particular de la Sancta Vera Cruz (signo), en la qual quiso por su amado Hijo se ofreciese su vida, porque en el madero menoscabase los daños que en el madero auían venido e para que con su muerte destruiese la nuestra y nos diese vida, con la qual siempre biuamos, por no ser yngratos ni desagradecidos, no nos oluidando de tan señalado beneficio, con tanta crecida y entrañable deuoción que podemos, ...»100.

Esa voluntad de no olvidar el beneficio infinito de la Cruz y corresponder a Dios en señal de agradecimiento se manifiesta el Domingo de Ramos cuando los cofrades hacen cabildo general, y «en reuerencia de la Passión que Jesuchristo pasó en el Árbol de la Vera Cruz por nos saluar», "se les requiera si están confesados y se les hagan que se pidan perdón unos a otros». Así, reconciliados con los demás y con Dios, acudirán a su capilla el Jueves Santo a las cinco de la tarde «que venga cada uno confessado e comulgado», para proceder después a la procesión por la noche disciplinándose públicamente, «ceñidos cordones de sant Francisco», saliendo a las diez de la noche "para que bolua-

96 J. SÁNCHEZ HeRreRo, «Las cofradías sevillanas. Los comienzos», en Las cofradías de Sevilla. Historia, Antropología, Arte, Sevilla, 1991, p. 9.

${ }_{97}$ G. RuBIo, La custodia franciscana de Sevilla. Ensayo histórico sobre sus orígenes, progresos y vicisitudes (1220-1499), Sevilla, 1953, p. 665-668.

98 Una definición de confradía de penitencia en J. SÁNCHEZ HERRERO, «Las cofradías sevillanas. Los comienzos», en Las cofradías de Sevilla. Historia, Antropología, Arte, Sevilla, 1991, p. 28.

${ }^{99}$ Regla de la Cofradía de la Santísima Vera Cruz, estudios de Teresa Laguna Paúl y José Sánchez Herrero, Sevilla 1999, p. 45.

100 Ibid, pp. 69-70. 
mos después de las doze, por ganar las gracias, perdones y jubileos que tenemos del Juebes y Viernes Santo»101.

En resumen, un esquema penitencial perfecto y enormemente ortodoxo en orden a la salvación del alma: práctica de los sacramentos, vías «oficiales» y de institución divina para la recepción de la gracia divina: de la confesión, con el consiguiente perdón de la culpa derivada de los pecados, y de la comunión, centro de la religión católica y también dotado de cualidades purificadoras ${ }^{102}$; penitencia corporal; y remisión ante Dios de las penas temporales merecidas por los pecados ya perdonados en cuanto a su culpa en virtud de las indulgencias concedidas por la Iglesia a que se hace referencia en la Regla ( $«$ del Juebes y Viernes Santo»). Y en todo ello, el claro sello del franciscanismo, inconfundible para cualquier persona de la época: el cordón de San Francisco, el distintivo más característico de la Orden franciscana, dotado, también, de un valor penitencial ${ }^{103}$.

La procesión debía ser, desde luego, bastante aleccionadora. En la noche, precedidos de uno de los mayordomos con la seña negra con cruz colorada de la hermandad, los cofrades de sangre de dos en dos, flagelándose con una disciplina «de manojo con sus rodezuelas», y cada cuatro o cinco de éstos, un cofrade de luz, todos con el rostro cubierto por el capirote, «su aparejo de camisa y disciplina», las camisas largas hasta el suelo y ceñidos los cordones de San Francisco, descalzos o con alpargatas bastas. Detrás de todos, «un Crucifixo grande en su cruz» y los frailes del convento de San Francisco. La única música, «quatro trompetas tañendo de dolor» 104 .

101 Todas estas citas en ibid,pp. 73-74.

102 Francisco de Osuna, siguiendo la doctrina del dominico Santo Tomás de Aquino (s. th. 3. p. q. 79 , a. 3 y 4) y los franciscanos Alejandro de Halles y Gabriel Biel (4 p. q. 46), explica que la comunión recibida correctamente «da perdon y remission de los pecados a culpa y a pena» (Francisco de OsunA, Gracioso combite de las gracias del sancto sacramento del altar, Burgos, Juan de Junta, 1537, f. 29v). Todo el capítulo séptimo del Gracioso convite se dedica a explicar cómo una de las gracias «que te haze la sagrada communion es apartar de ti tus pecados». Las obras de Halles y Biel se encontraban con facilidad en las bibliotecas franciscanas andaluzas, en ediciones de la época impresas en el extranjero (véase, por ejemplo, Rafael M. PÉREZ GARCÍA, «La biblioteca del convento de San Diego de Cazalla: libros de autor franciscano (1646)», Archivo hispalense 258 (2002), 106; Rafael M. PÉrez GARcía, «La biblioteca del convento de San Antonio de Padua de Lora del Río: libros de autor franciscano (1646)», Hispania Sacra 116 (2005), 765-777; K. WAGNER, «Los autores franciscanos de la desaparecida biblioteca del Convento de San Francisco de Sevilla», Archivo hispalense 192 (1980), 212).

103 N. TORRES BALlesteros, «El cordón franciscano en el arte gótico peninsular. Significado y ejemplos plásticos: casa del cordón y otros edificios civiles», en Ma del Mar GraÑa CID (ed.), El franciscanismo en la Península Ibérica. Balance y perspectivas, Barcelona, 2005, p. 862 y 890.

104 Los datos sobre la procesión en Regla de la Cofradía de la Santísima Vera Cruz, Sevilla 1999, pp. 73-74 y 84 .

Hispania Sacra, LXI

124, julio-diciembre 2009, 587-620, ISSN: 0018-215-X 
La cofradía de la Vera Cruz de Sevilla se funda en 1448, a partir de una congregación previa de devotos de la Vera Cruz que habría existido desde principios del siglo XV. En 1478, la cofradía se trasladaría a una capilla dentro del recinto del convento casa grande de San Francisco ${ }^{105}$. Y al menos desde 1480, según se deduce de las palabras del Abad Gordillo, habría practicado, la primera, la disciplina pública ${ }^{106}$. Según este modelo de cofradía de penitencia de la Vera Cruz, aparecen y en el siglo XVI otras muchas en el ámbito del arzobispado de Sevilla con reglas prácticamente idénticas ${ }^{107}$ : Aznalcázar, Castilleja del Campo, Castilleja de la Cuesta, Dos Hermanas, Écija, Lora del Río, Marchena, Olivares, Palomares ${ }^{108}$, Villaverde del Río, etc.

Hay todavía una pieza de este puzzle que interesa mover: según Félix González de León, fue San Vicente Ferrer, durante su estancia en Sevilla en 1408 quien enseñó e instituyó la disciplina en algunas cofradías de la ciudad, siendo la de la Vera Cruz la primera en haber tenido disciplinantes ${ }^{109}$. Sánchez Herrero admite que la labor de San Vicente Ferrer creando compañías de disciplinantes durante sus viajes y prédicas por Europa y España desde 1399 también pudo ser uno de los elementos que se hallen en el origen de las cofradías sevillanas de penitencia ${ }^{110}$. Y sabemos a ciencia cierta que las prácticas de autoflagelación de las compañías de disciplinantes despertaban recelos en la Iglesia y en la que era entonces órgano principal de gestión y defensa de la Fe, la Universidad de París. No en vano, el canciller de ésta, Jean Gerson, escribió desde el Concilio de Constanza (1414-1418) a Vicente Ferrer exponiéndole sus reservas sobre los modos de disciplina existentes entonces en España por ser causa de enfermedad y tullimiento en quienes la practican, falta de asistencia a los oficios divinos de la Iglesia, escándalo y malos pensamientos para terceros por la desnudez o impudicia de los flagelantes. Pero especialmente preocupaba a Gerson que los disciplinantes sustituyesen la práctica sacramental de la confesión y la Eucaristía por la simple disciplina física ${ }^{111}$. Que Gerson se preocupase por todo esto, no debe extrañarnos, todo lo contrario, ya que como experto teólogo conocía muy bien el amplio reper-

105 Los datos sobre la cofradía en ibid,p. 66.

106 J. SÁNCHEZ HERRERO, «Las cofradías sevillanas. Los comienzos», en Las cofradías de Sevilla. Historia, Antropología, Arte, Sevilla, 1991, p. 33.

${ }_{107}$ Regla de la Cofradía de la Santísima Vera Cruz, Sevilla 1999, p. 66.

108 J. SÁnChez Herrero \& S. M. PÉrez GonZÁLEZ, CXIX Reglas de hermandades y cofradías andaluzas. Siglos XIV, XV y XVI, Huelva, 2002, p. 39.

${ }^{109}$ Félix GONZÁLEZ DE LEÓN, Historia crítica y descriptiva de las cofradías de penitencia, sangre y luz, fundadas en la ciudad de Sevilla, ..., edición facsímil de la edición sevillana de 1852, Sevilla, 1994, pp. 8-10, 128, 147-148.

110 J. SÁNCHEZ HeRreRo, «Las cofradías sevillanas. Los comienzos», en Las cofradías de Sevilla. Historia, Antropología, Arte, Sevilla, 1991, pp. 31-32.

${ }^{111}$ Regla de la Cofradía de la Santísima Vera Cruz, Sevilla 1999, pp. 86-87. 
torio de las herejías medievales, y tenía su mente habituada a juzgar los fenómenos contemporáneos por comparación con los precedentes.

Entre esas herejías estaba la de los «flagelantes», un movimiento iniciado en Italia en 1260, año apocalíptico según el joaquinismo, que defendía que un hombre podía conseguir el perdón de sus pecados y la consiguiente salvación con la participación en las procesiones de flagelantes, al margen de la Iglesia. Los flagelantes se extendieron rápidamente por Alemania y Francia, y aunque reprimidos, mantuvieron una existencia soterrada que permitió un gran resurgimiento a partir de 1348, en relación directa con la Peste Negra interpretada por la mentalidad medieval en términos de castigo divino. Si bien algunas de las procesiones de flagelantes estaban dirigidas por el clero, otras muchas no, y miles de flagalentes, organizados en «portadores de la cruz», «fraternidad de flagelantes» 0 «fraternidad de la cruz» recorrieron Europa desde el norte de Francia y Flandes hasta Bohemia, entendiendo la autoflagelación como una imitatio Christi colectiva.

En las décadas siguientes, la Iglesia y los inquisidores persiguieron a los flagelantes, acabando con un movimiento del que todavía hacia 1480 se seguían castigando adeptos. Es en este contexto histórico en el que se sitúan las procesiones de flagelantes organizadas por San Vicente Ferrer en España, sur de Francia e Italia ${ }^{112}$. Los flagelantes de San Vicente, de los que este habla en sus escritos, oían con fervor la Misa, confesaban sus pecados y comulgaban los domingos, encuadrándose, por lo tanto, dentro de la práctica y doctrina penitencial de la Iglesia. Esto lo acompañaban, eso sí, con lo que era su rasgo principal, la devoción a Jesucristo y su Pasión ${ }^{113}$, y de una brutalidad física considerable: «No se disciplinaban estos penitentes así como quiera, sino con tanto rigor y denuedo que la sangre llegaba a tierra, y en algunos de ellos era tanto el dolor que tenían de sus delitos, que era menester quitarles los azotes de las manos porque no se matasen». A veces se hallaron entre las ropas de estos disciplinantes «pedazos de carne tan grandes como un dedo»114.

En realidad, la actuación de San Vicente Ferrer a comienzos del siglo XV es un intento de integración del fenómeno flagelante en la práctica penitencial eclesiástica ordenándolo de un modo ortodoxo. El mismo significado tienen las reglas de las cofradías bajoandaluzas de la Vera Cruz, de inspiración franciscana. Sin embargo, los orígenes turbulentos y salpicados de herejía del movimien-

\footnotetext{
${ }^{112}$ Sobre los flagelantes medievales, N. CoHn, En pos del Milenio. Revolucionarios milenaristas y anarquistas místicos de la Edad Media, Barcelona, 1972, pp. 135-157.

${ }^{113}$ San Vicente FerRer, Biografía y escritos de San Vicente Ferrer, dirección e introducciones de los padres José M. de Garganta y fr. Vicente Forcada, Madrid, 1956, pp. 49-51.

114 Ambas citas tomadas de la Vida de San Vicente, en Biografía y escritos de San Vicente Ferrer, Madrid, 1956, p. 129.

Hispania Sacra, LXI

124, julio-diciembre 2009, 587-620, ISSN: 0018-215-X
} 
to flagelante planearon todavía durante mucho tiempo sobre esas cofradías, arrojando sobre ellas un halo de sospecha del que se hacía eco, a comienzos del siglo XVII, Covarrubias, cuando en la voz «Flagelantes» de su Tesoro de la lengua castellana recordaba a aquellos herejes extendidos por buena parte de Europa que "yvan pidiendo limosna, azotándose y abriéndose las carnes a azotes ... dezian que para alcançar perdón de los pecados era mas eficaz aquella disciplina de azotes que la confession sacramental», que fueron condenados en tiempos de los Papas Gregorio X y Juan XXII, y respecto a los cuales intentaba marcar las distancias intentando mostrar la absoluta inexistencia de nexos con prácticas admitadas por la Iglesia: «La diciplina que oy dia se usa en toda la Iglesia Católica no tiene que ver con este género de flagelantes; pues las cofradías della están instituydas con bulas apotólicas y el intento es tan diferente que de ordinario van los cofrades confessados y comulgados...», y, añade en tono que le delata en su intento de reescritura histórica, que "y si alguno ay que no proceda con la devoción y decencia que deve no es justo que por él pierdan los demás» ${ }^{115}$.

En definitiva, en la génesis de las cofradías bajoandaluzas de la Vera Cruz hemos de valorar, necesariamente, la influencia del contexto europeo flagelante y de San Vicente Ferrer, el carácter omnipresente de la figura de Cristo Crucificado cuya figura satura emocionalmente el ambiente social bajomedieval ${ }^{116}$, y la intensa acción de la Orden franciscana propagando la devoción a su persona y Pasión en un sentido ortodoxo.

En este punto es interesante recordar un testimonio de Francisco de Osuna que nos informa acerca de un aspecto poco tratado como es el modo en que procedían los franciscanos en su propagación de las cofradías de la Vera Cruz y Pasión. En los últimos años de su vida, Osuna recuerda a su amigo fray Juan Navarrete, fraile de la Provincia de Castilla cuyo sepulcro en Pontevedra dijimos que visitó, que se fue «por toda España a predicar, y fundó en muchas partes la confradia de la passion», desarrollando una labor frenética «que en vn dia sembraua y cogia aquel sieruo de dios, y ordenaua que dixessen los clerigos cada viernes vna missa de la passion, y viniesse el pueblo a la oyr, de manera que hazia el mas fructo en vn sermon, que otro en vn año» ${ }^{117}$.

Relacionado con la voluntad de integrar-relacionar la penitencia en y con la práctica sacramental de la Iglesia, está el hecho de que Navarrete extendía de modo paralelo las cofradías del Santísimo Sacramento, contando con el apoyo

115 Sebastián de Covarrubias, Tesoro de la lengua castellana o española según la impresión de 1611, con las adiciones de Benito Remigio Noydens publicadas en la de 1674, edición preparada por Martín de Riquer, Barcelona, 1993, p. 598.

116 J. Huizinga, El otoño de la Edad Media, Madrid, 1990, p. 269.

${ }^{117}$ Francisco de Osuna: Quinta parte del abecedario espiritual, Burgos, 1542, f. 137r-v. 
de la célebre doña Teresa Enríquez ${ }^{118}$, señora de Torrijos conocida como «La Loca del Sacramento», y siguiendo el ejemplo del predicador italiano fray Cherubino de Espoleto, que en la década de 1480 difundió la veneración al Santísimo Sacramento, haciendo grandes sermones por los pueblos e instituyendo cofradías de personas devotas del Santísimo ${ }^{119}$.

\section{Literatura franciscana sobre la Vida y Pasión de Cristo}

Al interés social por la Pasión de Cristo contribuyó no poco, también, la amplia literatura finimedieval y del siglo XVI escrita en castellano y dedicada a la vida de Cristo, entre la que sobresale la franciscana ${ }^{120}$. El impacto de ésta en la Baja Andalucía del Renacimiento es profundo.

En 1496 se imprimió en Granada el Libro de la vida de nuestro Señor Jesucristo de fray Francesc Eiximenis ${ }^{121}(\dagger 1409)$, corregido por el arzobispo de la ciudad fray Hernando de Talavera. Diez años más tarde, en 1506, las Coplas de Vita Christi de fray Íñigo de Mendoza (c. 1425-1507?) veían la luz en Sevi$1 \mathrm{l}^{122}$. Antes, en 1492, las prensas sevillanas de Ungut y Polono habían sacado el Floreto de San Francisco, con su vida y milagros ${ }^{123}$, donde el lector podía aprender del Santo, «el perfecto ymitador e seguidor de Ihesu Cristo»124. El anónimo franciscano Fasciculus mirrhe, «en el qual devotamente se trata de los misterios de la sacratissima passion de nuestro redemptor Jesuchristo»125, se publica repetidamente en Sevilla: en 1517, 1518, 1524, 1531, 1536, 1550. Del

118 Sobre esta mujer, R. M. PÉrez GarCía, Sociología y lectura espiritual en la Castilla del Renacimiento, 1470-1560, Madrid, 2005, pp. 210-211.

119 Francisco de Osuna, Quinta parte del abecedario espiritual, Burgos, 1542, f. 137r-v; Pedro de Salazar, Coronica y Historia de la Fvndacion y Progresso de la Provincia de Castilla..., Madrid, 1612, pp. 149-150. Doña Teresa Enríquez, a la que Osuna llama «patrona de la cofradia del sancto Sacramento», proporcionó a Navarrete grandes cantidades de objetos para el digno culto a la Eucaristía, que éste iba distribuyendo por las iglesias de los pueblos que iba recorriendo, especialmente en las zonas más «salvajes» en este sentido, como Asturias y Galicia. Sobre las relaciones entre el franciscanismo español e italiano, véase R. M. PÉrez GARCía, «Pensamiento teológico y movimientos espirituales en el siglo XVI», en A. L. CoRTés PeÑa: Historia del cristianismo, Madrid, 2006, tomo III, p. 59, y sobre la influencia de la espiritualidad italiana en España P. SÁINZ RodríGuEZ, Espiritualidad española, Madrid, 1961, pp. 73-109.

${ }^{120}$ Un repaso de la abundante literatura de la época escrita en romance castellano dedicada a la vida y misterio de Cristo en M. ANDrés MARTín, Historia de la mística de la Edad de Oro en España y América, Madrid, 1994, p. 242.

${ }^{121}$ C. HAEBLER, Bibliografía ibérica del siglo XV, Madrid, 1992, núm. 711.

122 F. EsCUDERO Y PEROSSO, Tipografía hispalense. Anales tipográficos de la ciudad de Sevilla desde el establecimiento de la imprenta hasta fines del siglo XVIII, Madrid, 1984, p. 129.

${ }^{123}$ F. EsCudero y Perosso, Tipografía hispalense, Madrid, 1984, pp. 82-83.

124 J. M. Arcelus Ulibarrena, Floreto de San Francisco, Madrid, 1998, p. 572.

${ }^{125}$ F. Escudero y Perosso, Tipografía hispalense, Madrid, 1984, p. 190.

Hispania Sacra, LXI

124, julio-diciembre 2009, 587-620, ISSN: 0018-215-X 
franciscano castellano fray Francisco Tenorio, su Passio duorum. Tratado de devotísimas y muy lastimosas contemplaciones de la Pasión del Hijo de Dios, se imprime en Sevilla en 1534, 1539 y 1550. De las Epistolas y evangelios del franciscano Ambrosio Montesino, se imprimen en Sevilla cinco ediciones antes de 1559: $1526,1537,1540,1549$ y otra sin data pero fechable entre 1532-1545. Y la Vita Christi del cartujano Ludolfo de Sajonia, vertida al castellano por el mismo Montesino allá por el cambio de siglo, se imprime repetidamente en la imprenta de los Cromberger: las partes segunda y tercera en 1520-1521; las cuatro partes en 1530-1531, 1536-1537 y 1551, y otra vez las partes segunda, tercera y cuarta en 1543-1544. A estas obras hemos de sumar las de dos escritores franciscanos andaluces, maestros de la mística del recogimiento: la Primera parte del libro llamado Abecedario spiritual: que trata de las circunstancias de la sagrada passion del hijo de dios, de fray Francisco de Osuna, impresa en Sevilla en 1528; y la Subida del Monte Sión, de fray Bernardino de Laredo, impresa en Sevilla en 1535 y 1538 , y cuya segunda parte «trata de los muy altos mysterios de la humanidad de Cristo» ${ }^{26}$, tema importante si consideramos «que no ay otro camino que la humanidad de Cristo para la divinidad»127. Asimismo, también en el Segundo Abecedario Espiritual y el Gracioso convite de Osuna, aparecidos en Sevilla en 1530-1531, se encuentra propuesta continuamente la meditación de la Vida de Cristo con abundante materiales para su ejercicio ${ }^{128}$.

Estamos, pues, ante una enorme masa de literatura franciscana sobre la vida de Cristo, y muy especialmente sobre su Pasión, que ronda la treintena de ediciones. Es evidente que no toda esta producción estaba destinada a Sevilla y Andalucía, ya que durante este periodo Sevilla es el principal centro tipográfico de la Península Ibérica y desde ella se distribuyen miles de libros al resto de la Península y América. No obstante, sí que se encontraban en las librerías de la ciudad, como en la de los Cromberger, donde en 1528-1529 se podía adquirir el Primer Abecedario o el Vita Christi del cartujano ${ }^{129}$. Además, y al mismo

${ }^{126}$ Bernardino de LAREdo, Subida del Monte Sión, edición realizada por Alegría Alonso González, Mercedes García Trascasas y Bertha Gutiérrez Rodilla, Madrid, 2000, p. 185.

127 Ibid, p. 194.

128 Así, en el Gracioso convite, f. 105v-108r, hace un repaso de la vida de Cristo; en el Segundo Abecedario Espiritual, los tratados VI, X y XVII vuelven a centrarse en la Pasión; aparte de las obras de Osuna publicadas tras su muerte, el Quinto Abecedario, en el que propone meditar todos los miércoles sobre la muerte de Cristo y los viernes en su Pasión, ofreciendo instrumentos nemotécnicos para ello (Francisco de OsunA, Quinta parte del abecedario espiritual, Burgos, 1542, f. 76v-77v), y el Sexto Abecedario dedicado a las llagas de Cristo, o el sermón latino sobre la Pasión contenido en su Trilogium evangelicum. Las referencias bibliográficas de todas las obras y ediciones mencionadas en esta nota se encuentran en R. M. PÉREZ GARCÍA, La imprenta y la literatura espiritual castellana en la España del Renacimiento, 1470-1560, Gijón, 2006, pp. 310-314.

129 C. GRIFFIN, «Un curioso inventario de libros de 1528», El libro antiguo español. Actas del I Coloquio Internacional, Salamanca, 1988, pp. 218 y 212. 
tiempo, otras obras franciscanas sobre la vida de Cristo impresas fuera de Andalucía podían ser adquiridas en las librerías de Sevilla, especializadas en abastecer no solo la ciudad y el mercado americano, sino también el andaluz ${ }^{130}$ : así, en 1533 una librería de la ciudad disponía de cuatro ejemplares del Vita Christi de San Buenaventura ${ }^{131}$; en 1529 en la librería e imprenta de los Cromberger había 19 ejemplares del Passio duorum, publicado en 1526 en Valladolid ${ }^{132}$, y 190 Coplas de vita christi de fray Íñigo de Mendoza ${ }^{133}$; y en 1540, los devotos de la Pasión encontraban miles de ejemplares sobre la Pasión en la librería de Juan Cromberger: 800 horas de la Pasión, 550 Fasciculus mirrhe, 290 «Pasiones», otras 500 horas de la Pasión, 93 Coplas de Vita Christi, etc ${ }^{134}$. Además, esta literatura era accesible a aquella sociedad: si los gruesos infolios, como el de Eiximenis, presentarían inevitablemente precios altos, la mayor parte de estas obras eran libros impresos en cuarto, un formato más manejable y económico, aparte de otros mucho más baratos, como las Coplas de Íñigo de Mendoza, de las que Hernando Colón compró un ejemplar por 34 maravedís ${ }^{135}$, cantidad en torno a la que se movía el salario diario de un jornalero' ${ }^{136}$. Y aquí estamos llegando al punto en que la civilización escrita altomoderna penetró hasta los últimos rincones de aquella sociedad de la mano de escritos de pequeñas dimensiones que van desde las coplas y los pliegos sueltos hasta la simple estampa o el papel pintado. Recordemos a aquella sevillana fallecida en 1553, Isabel Gutiérrez, esposa de un cosmógrafo, entre cuyos bienes había «un papel de una figura de christo» ${ }^{137}$, o aquella otra Mencia de Colombres (muerta en 1557), que tenía «una verónica pintada en papel»y «tres ymagenes de papel»138.

130 C. GRIFFIn, Los Cromberger. La historia de una imprenta del siglo XVI en Sevilla y Méjico, Madrid, 1991, pp. 69-70; N. MAILlARD, «El mercado del libro en Sevilla durante el reinado de Felipe II», en La memoria de los libros. Estudios sobre historia del escrito y de la lectura en Europa y América, Salamanca, 2004, tomo II, pp. 547-566.

131 (A)rchivo (H)istórico (P)rovincial de (Se)villa: (P)rotocolos (N)otariales, leg. 45.

132 C. GRIFFIN, «Un curioso inventario de libros de 1528», El libro antiguo español. Actas del I Coloquio Internacional, Salamanca, 1988, p. 219. Se trata con toda seguridad de la edición pucelana de 1526, ya que no existe otra anterior a 1529 (R. M. PÉREZ GARCÍA, La imprenta y la literatura espiritual castellana en la España del Renacimiento, 1470-1560, Gijón, 2006, p. 319).

133 C. GRIFFIN, «Un curioso inventario de libros de 1528», El libro antiguo español. Actas del I Coloquio Internacional, Salamanca, 1988, p. 206.

${ }^{134}$ C. GRIFFIN, «El inventario del almacén de libros del impresor Juan Cromberger: Sevilla 1540», en M. L. López-Vidriero \& P. M. CÁTedRA, (dirs.): El libro antiguo español, Salamanca, 1998, IV, pp. 257-373, 292, 293, 297, 299, 308.

135 F. Escudero y Perosso, Tipografía hispalense, Madrid, 1984, p. 129.

136 Sobre el precio de la literatura espiritual en la época, R. M. PÉREZ GARCÍA, Sociología y lectura espiritual en la Castilla del Renacimiento, 1470-1560, Madrid, 2005, pp. 331-339.

137 AHPSe: PN, leg. 5896.

138 AHPSe: PN, leg. 17537. Para el caso de Cataluña, la relevancia de las estampas y papeles escritos y/o pintados ha sido puesta de manifiesto por M. PEÑA DÍAZ, Cataluña en el Renacimiento: libros y lenguas, Lleida, 1996, pp. 244-249. En relación con la cuestión de la literatura popular, es fundamen-

Hispania Sacra, LXI

124, julio-diciembre 2009, 587-620, ISSN: 0018-215-X 
Ejemplo destacado de esa literatura popular fue también el pliego suelto impreso en Sevilla en 1593 por Juan de León sobre «La vida del bienaventurado San Francisco», de 24 páginas (3 pliegos de imprenta) que contaba la vida del Santo centrándose en los episodios más celebres de la tradición biográfica franciscana y recordando que «todo su estudio, asi en publico como en secreto, era cerca de la Cruz y Pasión de Nuestro Redentor» ${ }^{139}$. Finalmente, y por otra parte, existe una amplia constancia documental de la recepción de la literatura franciscana sobre la vida y Pasión de Cristo en la sociedad sevillana del Renacimiento ${ }^{140} \mathrm{y}$, por extensión, en la Baja Andalucía.

\section{La cruz en el paisaje}

Por último, los franciscanos llevaron a cabo un enorme esfuerzo por «colonizar» el paisaje, colocándolo físicamente bajo el signo de la cruz. Ello se produce tanto en el espacio privado-doméstico, del que me he ocupado en otro lugar ${ }^{141}$, como en el espacio público, urbano y rural. En este sentido, es muy clara la actuación de sus misioneros en América, que se repite en Andalucía. Los primeros apóstoles franciscanos de México, descalzos de la Provincia de San Gabriel, los célebres Doce Apóstoles ${ }^{142}$, profundamente emparentada espiritual e históricamente con la de los Ángeles, y el primer obispo, fray Juan de Zumárraga, extienden la devoción a la Cruz entre los indios, y ella produce magníficos frutos. Según Motolinía en su Historia de los indios de la Nueva España (c. 1541), Zumárraga, antes de regresar a España abandonó Nueva España «dejando primero levantada la señal de la cruz, de la cual comenzaron a pintar muchas; y como en esta tierra hay muy altas montañas, también hicieron altas y grandes cruces, a las cuales adoraban, y mirando sanaban algunos que aún estaban heridos de la idolatría» ${ }^{143}$.

tal P. M. CÁTEDRA, Invención, difusión y recepción de la literatura popular impresa (siglo XVI), Mérida, 2002.

139 A. Cruz Casado, «La vida de San Francisco de Asís en un pliego sevillano del siglo XVI», en M. Peláez del Rosal (dir.), El franciscanismo en Andalucía. III Curso de Verano, Córdoba, 1999, pp. 599-610.

140 R. M. PÉrez García, Sociología y lectura espiritual en la Castilla del Renacimiento, 14701560, Madrid, 2005, pp. 270-275.

${ }^{141}$ R. M. Pérez García, «Imitatio Christi. Arte religioso doméstico, devociones privadas y espiritualidad en la sociedad sevillana del Renacimiento, 1520-1570», en F. LORENZANA DE LA PUENTE \& F. J. Mateos Ascacíbar (coords.), Arte, poder y sociedad y otros estudios sobre Extremadura, Llerena, 2006, pp. 55-69

142 Sobre estos, véanse Ch. Duverger, La conversión de los indios de Nueva España, México, 1993, pp. 27-30, y A. RuBIAL GARCía, La hermana pobreza. El franciscanismo: de la Edad Media a la evangelización novohispana, México, 2000.

${ }^{143}$ Toribio de Motolinía, Historia de los indios de la Nueva España, edición, introducción y notas de Georges Baudot, Madrid, 1991, p. 128. 
Los avisos destinados a los curas escritos por el obispo franciscano andaluz fray Francisco de Toral, ya de la generación siguiente a la de los Doce Apóstoles, son muy esclarecedores del cómo de esa insistente difusión franciscana de la cruz: "Pónganse cruces a las entradas y salidas de los pueblos y a las entradas de la Iglesia y patios, y déseles a entender a los indios como en ella obró Cristo nuestro Señor el misterio de nuestra redempción, y en llegando a la Cruz. se hinquen de rodillas y adoren en ella a nuestro Señor Jesucristo, alzando los ojos del alma a la contemplación de este misterio» ${ }^{144}$.

Los efectos del apostolado crucífero no se hicieron esperar, y así, entre los indios que frecuentaban los sacramentos se producían visiones: "Algunos de estos naturales han visto al tiempo de alzar la hostia consagrada, unos un niño muy resplandeciente, otros a Nuestro Redentor crucificado, con gran resplandor, y esto muchas veces» ${ }^{145}$. Finalmente, el paisaje mejicano queda cristianizado-cristificado: "Está tan ensalzada en esta tierra la señal de la cruz por todos los pueblos y caminos, que se dice que en ninguna parte de la cristiandad está más ensalzada, ni adonde tantas ni tales ni tan altas cruces haya... Delante de esta señal de la cruz han acontecido algunos milagros... los Indios la tienen en tanta veneración, que muchos ayunan los viernes y se abstienen aquel día de tocar a sus mujeres, por devoción y reverencia de la cruz» ${ }^{146}$.

En este aspecto, América no era sino correlato de Andalucía y de una Sevilla que era puerta hacia aquella. Francisco de Osuna se hace eco de ello cuando escribe: "Fuera de los lugares, entre los caminos, sobre las yglesias, y quasi doquiera que vamos, encontramos con la cruz del Señor para renovar su memoria en nuestros coraçones» ${ }^{147}$. En Sevilla, también, había llegado el Via Crucis en 1520, de la mano de don Fadrique Enríquez de Ribera, a la vuelta de su viaje a Jerusalén ${ }^{148}$.

Tal era la omnipresencia del signo de la cruz en el paisaje, que su ubicación en determinados lugares considerados poco dignos llegó a preocupar a las autoridades civiles y religiosas. Así, el 4 de junio de 1601, y en presencia del Asistente de la ciudad, se celebró en Sevilla una Junta y congregación de perlados y maestros para estudiar la cuestión de "la grande indecencia con que en muchas callexuelas y partes no decentes estavan figuradas y pintadas muchas cruces». Uno de los frailes participantes en ella escribía días después su parecer, condicionado por el carácter cosmopolita de la ciudad de Sevilla,

\footnotetext{
144 E. Toral Peñaranda, Fray Francisco de Toral, apóstol de las Indias, Alcalá la Real, 2004, p. 41.

145 Toribio de Motolinía, Historia de los indios de la Nueva España, Madrid, 1991, p. 260.

146 Ibid, pp. 265-266.

147 Francisco de Osuna, Primera parte del libro llamado Abecedario spiritual, Sevilla, 1528, f. 5r.

148 J. SÁnCHEZ HERRERo, «Las cofradías sevillanas. Los comienzos», en Las cofradías de Sevilla. Historia, Antropología, Arte, Sevilla, 1991, p. 33.
}

Hispania Sacra, LXI

124, julio-diciembre 2009, 587-620, ISSN: 0018-215-X 
verdadero escenario de la representación de la Fe: «aunque en todas las ciudades de estos reynos y de la christiana religion deua mucho resplandecer el culto divino, y honra y reverencia de las ymagines y en especial de la santa cruz, pero en ninguna tanto como en esta», debido a "que esta ciudad es como emporio y mercado del Orbe, es como plaça del mundo, y como aduana donde concurren todas las naciones, aqui acuden moros, alarabes, etyopes, turcos, persas, asyrios, y chaldeos; aqui de toda Europa, ungaros, flamencos, alemanes, ytalianos, franceses, yngleses, y de todas esas yslas del Setentrion; aqui finalmente concurren de todas esas remotissimas indias orientales y ocidentales, y no dudo acudir tambien aqui hereges». Ante esas gentes, el espectáculo deplorable de cruces públicas rodeadas de suciedad, motivo de vergüenza y mal ejemplo: "¿qué dirá el judio, qué dira el herege, y qué dirá el moro y pagano, viendo pintada la cruz a la qual adoramos los christianos fieles con la adoracion latria que al mismo Dios, junto a muladares, o en callexuelas que han sido muladares, y aun lo tornaran a ser?, y en otros lugares donde las bestias las puedan ensuçiar, y los perros orinar, y los hombres, ... luego otro dia despues de la dicha congregacion fui a la yglesia mayor y en el primer rincon de la torre antes de pasar el arco vi una orina corriendo recien echada por medio de una cruz de almagra que estaua hecha en el mismo rincon ... y esto era entre las siete y las ocho de la mañana, pues si esto se hizo en lugar tan publico, ¿qué se puede esperar de las callexuelas y rincones lobregos y escusados?».

A pesar de su repugnancia a tal falta de respeto y religión, en el parecer de nuestro fraile primará un criterio fundado en el deseo de evitar dar argumentos a los múltiples enemigos de la fe presentes en la ciudad: «pero por estar pintadas grande numero de cruces en muchas calles de esta ciudad borrarlas todas de las callexuelas seria grande nota y por uentura tomarian de ay ocasion los hereges (sy ay algunos encubiertos) para escriuir a su tierra, que digan en sus conciliabulos y predicas, con intento de rehazerse en el sacrilego error que tienen con las ymagenes, que ya en Sevilla se borran». Por ello, concluye pidiendo que únicamente se quiten, «como al descuydo, las que estuvieren en lugares indeçentes, y en lo por venir ... que no se pinten cruces ni aun otras imagenes, sino en lugares muy decentes y seguros de semejantes yrreverencias y desacatos» ${ }^{149}$. El asunto, que lo seguimos encontrando en la Sevilla de los años siguientes $^{150}$, revela cómo la Cruz de Cristo había ido conquistando el paisaje ur-

\footnotetext{
149 Todas estas citas están extraídas del documento conservado en Archivo General del Arzobispado de Sevilla: Asuntos Despachados, leg. 1: «Sobre quitar Pinturas y Cruces de lugares inmundos».

150 A. Domínguez Ortiz, Historia de Sevilla. La Sevilla del siglo XVII, Sevilla, 1984, pp. 46-47. Félix GonZÁlez de LEón, Noticia histórica del origen de los nombres de las calles de esta ... ciudad de Sevilla..., Sevilla, 1839, p. VII, se refiere todavía en el siglo XIX a las muchas cruces que hay en la ciudad de Sevilla.
} 
bano de Andalucía durante la Baja Edad Media y el Renacimiento ${ }^{151}$, y cómo la saturación de dicho espacio planteaba nuevas problemáticas derivadas del carácter de escenario público universal que para la Iglesia Católica tenía la Sevilla del Barroco.

151 Véase Y. V. Olmedo SÁncheZ, «Cruces e imágenes callejeras en la configuración de la ciudad moderna: estudio de algunos ejemplos en Andalucía», Actas del III Congreso de Historia de Andalucía. Andalucía moderna, Córdoba, 2003, tomo III, pp. 219-238.

Hispania Sacra, LXI

124, julio-diciembre 2009, 587-620, ISSN: 0018-215-X 